\title{
Optimization of the coefficient of performance of a heat pump with an integrated storage tank - A computational fluid dynamics study
}

\author{
Sifnaios, loannis; Fan, Jianhua; Olsen, Lars; Madsen, Claus; Furbo, Simon
}

Published in:

Applied Thermal Engineering

Link to article, DOI:

10.1016/j.applthermaleng.2019.114014

Publication date:

2019

Document Version

Peer reviewed version

Link back to DTU Orbit

Citation (APA):

Sifnaios, I., Fan, J., Olsen, L., Madsen, C., \& Furbo, S. (2019). Optimization of the coefficient of performance of a heat pump with an integrated storage tank - A computational fluid dynamics study. Applied Thermal Engineering, 160, [114014]. https://doi.org/10.1016/j.applthermaleng.2019.114014

\section{General rights}

Copyright and moral rights for the publications made accessible in the public portal are retained by the authors and/or other copyright owners and it is a condition of accessing publications that users recognise and abide by the legal requirements associated with these rights.

- Users may download and print one copy of any publication from the public portal for the purpose of private study or research.

- You may not further distribute the material or use it for any profit-making activity or commercial gain

- You may freely distribute the URL identifying the publication in the public portal 


\title{
Optimization of the Coefficient of Performance of a heat pump with an integrated storage tank - a Computational Fluid Dynamics study
}

\author{
Authors: Ioannis Sifnaios ${ }^{1}$, Jianhua Fan ${ }^{1}$, Lars Olsen², Claus Madsen², Simon Furbo ${ }^{1}$ \\ ${ }^{1}$ Department of Civil Engineering, Technical University of Denmark, Brovej 118, DK 2800 Kgs. Lyngby, Denmark \\ iosif@byg.dtu.dk \\ 2 Danish Technological Institute, Gregersensvej 1, DK 2630 Taastrup, Denmark
}

\begin{abstract}
The performance of a heating system consisting of a heat pump with an integrated storage tank was evaluated by means of Computational Fluid Dynamics (CFD) calculations. The aim of the investigations was to elucidate how thermal stratification in the tank would influence the COP of the system. Differently designed storage tanks were investigated under typical operation conditions. CFD models of heat storage tanks were developed and validated by experiments on a test tank. Calculations with the validated models were carried out in order to find the optimal tank design and system settings for achieving the highest possible COP. The investigated parameters were volume flow rate, tank geometry, diffuser design and tank wall material. Two different system COPs were defined: one based only on charge operation and the other on both charge and discharge operations. It was found that there is a direct connection between the thermal stratification inside the tank and the COP of the heating system. Higher degree of stratification leads to higher COP. For the ideal case where there is no mixing and no vertical thermal conduction in the tank and no heat loss from the tank, the system COP after a charge-discharge cycle is 3.69. When the effect of mixing is taken into account, the obtained COP of the system is decreased by approximately $9 \%$. If heat transfer to the tank wall and vertical thermal conduction are also taken into account, the obtained system COP is lowered by another $5 \%$. Moreover, the COP of a heating system with high flow rates can be significantly increased by a diffuser plate installed in the tank with a small distance to the inlet/outlet. The best performing system studied consisted of an insulated tall and slim tank with a h/d ratio of 3.64 and a perforated plate diffuser, giving a COP of 3.23 which was $32 \%$ higher compared to a case without a diffuser. The performance of the suggested system was not affected by variations of flow rates in the range from 0.12 to $0.24 \mathrm{~kg} / \mathrm{s}$.
\end{abstract}

Keywords: Coefficient Of Performance (COP), optimization, heat pump, Computational Fluid Dynamics (CFD), thermal stratification, heat storage tank

\section{Nomenclature}

$\begin{array}{ll}\mathrm{d} & \text { diameter }[\mathrm{m}] \\ \mathrm{h} & \text { height }[\mathrm{m}] \\ \mathrm{m}_{\text {steel }} & \text { mass of steel }[\mathrm{kg}] \\ \mathrm{m}_{\text {water }} & \text { mass of water }[\mathrm{kg}]\end{array}$




$\begin{array}{ll}C p_{\text {steel }} & \text { specific heat capacity of steel }[\mathrm{kJ} /(\mathrm{kg} \mathrm{K})] \\ C p_{\text {water }} & \text { specific heat capacity of water }[\mathrm{kJ} /(\mathrm{kg} \mathrm{K})] \\ \mathrm{T}_{\text {initial, steel }} & \text { average temperature of tank's steel at start of charge operation }[\mathrm{K}] \\ \mathrm{T}_{\text {final, steel }} & \text { average temperature of tank's steel at end of charge operation }[\mathrm{K}] \\ \mathrm{T}_{\text {initial, water }} & \text { average temperature of tank's water at start of charge operation }[\mathrm{K}] \\ \mathrm{T}_{\text {final, }} \text {, water } & \text { average temperature of tank's water at end of charge operation }[\mathrm{K}] \\ \mathrm{Q} & \text { amount of heat stored in tank }[\mathrm{kJ}] \\ V & \text { Volume }[\mathrm{L}] \\ \rho & \text { Water density }\left[\mathrm{kg} / \mathrm{m}^{3}\right] \\ \mathrm{V} & \text { Water velocity }[\mathrm{m} / \mathrm{s}] \\ \mathrm{L} & \text { Characteristic diameter }[\mathrm{m}] \\ \mu & \text { Water dynamic viscosity }\left[\mathrm{N} \mathrm{s} / \mathrm{m}^{2}\right] \\ \Delta t & \text { Time step [s] } \\ \Delta \mathrm{x} & \text { Mesh cell length [m] } \\ \mathrm{T}_{\text {CFD }} & \text { Temperature calculated by CFD model } \\ \mathrm{T}_{\text {Exp }} & \text { Temperature measured in experiment } \\ \mathrm{Qc} & \text { Heat output from the condenser } \\ \text { W } & \text { Power consumption of compressor } \\ \text { Abbreviations } & \\ \text { COP } & \text { Coefficient Of Performance } \\ \text { CFD } & \text { Computational Fluid Dynamics } \\ \text { TES } & \text { Thermal Energy Storage } \\ \text { UDF } & \text { User Defined Function }\end{array}$

\section{Introduction}

A problem that occurs frequently when using renewable energy sources is that supply and demand do not coincide in time. Regarding thermal energy, a solution to this problem could be thermal energy storage systems (TES) (Li et al., 2014). These systems are used as energy saving solutions, by storing available sensible heat energy in a specially designed tank (Shin et al., 2004). TES tanks are widely used in solar heating systems and domestic hot water systems. Research has proven that a well stratified tank can significantly increase the thermal performance of the system (Carola et al., 2012; Fan and Furbo, 2012a; Furbo et al., 2005; Hollands and Lightstone, 1989). In recent years, a lot of researchers have carried out studies for optimizing the thermal stratification in TES tanks by using CFD (Abdelhak et al., 2015; Castell et al., 2010; Fan and Furbo, 2012b; Knudsen and Furbo, 2004; Lohse et al., 2012; Yaïci et al., 2013). To assess CFD results regarding thermal stratification, a number of performance indicators have been suggested, namely temperature and streamline contours, Richardson and stratification numbers and water temperature (Bouhal et al., 2017).

Thermal stratification occurs naturally, but research show that thermal stratification in a tank can be affected by a number of parameters, namely the volume flow rate, tank design, heat losses, vertical thermal conduction in tank walls and mixing due to charge/discharge operations (Jordan and Furbo, 2005; Kozłowska and Jadwiszczak, 2018; Li et al., 2014; Nizami et al., 2013; Savicki et al., 2011; Shin et al., 2004). Although it is not clear which of these parameters has the largest effect on thermal stratification, a lot of researchers agree that the flow rate is one of the most important factors, especially during the charge process (Cristofari et al., 2003; Meyer et al., 2000; Wang et al., 2017). Turbulence and mixing created by 
inlet flow affect considerably thermal stratification, for this reason a lot of researchers have investigated various inlet designs and their effect on stratification. A sintered bronze conical diffuser is considered to favor stratification for both low and high flows (García-Marí et al., 2013; Moncho-Esteve et al., 2017). Others suggest that a divergent conical tube diffuser creates better thermal stratification due to better diffusion of water (Alizadeh, 1999). A diffuser plate close to the inlet was found to enhance stratification if cold water entered the top of the tank. However, in cases where hot water entered the top of the tank, it did not affect stratification (Zachár et al., 2003). Generally, any inlet design which restrains mixing of inlet water is able to maintain stratification for longer periods (Andersen et al., 2008; Fernandez-Seara et al., 2007; Shah and Furbo, 2003).

Other researchers investigated the effect of obstacles placed inside the tank on thermal stratification and concluded that the presence of an obstacle enhanced stratification. An optimal position for an obstacle was found to be 20-30 cm from the tank inlet (Arslan et al., 2006; Erdemir and Altuntop, 2016). In addition, some suggested that the obstacle types having a gap in the center appeared to cause better thermal stratification than those having a gap near the tank wall (Altuntop et al., 2005).

Other researchers have achieved good thermal stratification by using stratifiers, which are pipes placed inside the tank with holes at different heights (Dragsted et al., 2017). A different approach was suggested by Gómez where an auxiliary tank equipped with a heating coil was used, which injected hot water at different heights in the main tank for better thermal stratification (Gómez et al., 2018).

The effect of tank material on thermal stratification has also been investigated. A study was conducted on the inner lining of a tank finding that weak conducting inner lining material favors thermal stratification of water during charge and standby periods. As the lining material's thermal conductivity reaches zero the effect on stratification was enhanced (Gasque et al., 2015).

Heat pump systems are widely used in various industrial, commercial and residential applications due to their large potential for energy saving (Chua et al., 2010). Research has been conducted on coupling TES systems to heat pumps for shifting electrical loads from peak to off-peak hours, assisting the demand side management (Arteconi et al., 2013). Other researchers studied the connection of heat pumps to TES systems for domestic heating (D’Ettorre et al., 2019; Minetto, 2011). Ground source heat pumps connected to TES systems have been investigated for addressing the problem of heating and cooling imbalance in different areas (Zhu et al., 2014). Many experimental and theoretical studies have suggested different ways of improving and optimizing the COP of a system consisting of a heat pump and a thermal storage tank (Hu et al., 2015; Minetto, 2011; Wang et al., 2013). A CFD model of a heat pump heating the tank wall through a spiral has also been developed (Li and Hrnjak, 2018).

Although extensive research has been conducted regarding heat pumps and TES tanks, a CFD investigation of a system which optimizes its design and performance regarding thermal stratification has not been found in the literature. Meanwhile, the tank design parameters that affect thermal stratification in the tank have been extensively investigated, but the influence of these parameters on thermal performance of the heating systems has not been examined. In addition, there are no specific guidelines on design of a tank that creates the maximum thermal stratification and thus maximizing the COP of a heat pump system with an integrated heat storage tank.

In this paper, a heating system consisting of a heat pump and a TES tank is studied. The heat pump heats the water inside the tank. When the desired temperature is reached, the water is discharged and used for 
industrial purposes. It has been proven that, compared to a single heat pump giving the entire temperature lift in one operation, the COP of a heat pump is increased when multiple smaller heat pumps are used, which heat up the fluid step by step until it reaches the desired temperature (Wang et al., 2010). Based on this idea, the "Isolated System Energy Charging (ISEC)" project was developed (Olsen et al., 2016; Rothuizen et al., 2014), where instead of having multiple heat pumps connected in series, one heat pump was connected to a storage tank, using the tank in order to perform the gradual charge of water. This idea required large flow rates, which would lead to multiple passes of water through the heat pump and the tank, so that the temperature rise of each pass would be small (Olsen et al., 2015). In addition, for the optimal performance of this method, a highly stratified tank was of major importance. The reason is that, the COP of the heat pump for water temperatures around $40^{\circ} \mathrm{C}$ is much higher than that for $80^{\circ} \mathrm{C}$. In terms of energy consumption, it is beneficial to have low temperatures entering the heat pump. By having a stratified tank it is ensured that the water having the lowest temperature is located at the bottom of the tank and thus will enter the heat pump, leading to a higher system COP.

The scope of this paper was to examine the effect of the tank design on the COP of the tank-heat pump system during charge and discharge. Parameters such as the tank geometry, flow rate, diffuser plate geometry and tank material were investigated using CFD, in order to determine the effect of these parameters on the final performance of the heating system. Consequently, the best tank design was proposed, that maximizes the thermal stratification inside the tank and thus giving the largest system COP. This research was done as a part of the "Highly Efficient and Simplified Thermodynamic Cycle with Isolated Heating and Cooling - Cost Optimized (ISECOP)" project with an ultimate goal to demonstrate the optimized system solution (Madsen, 2017).

\section{Methodology}

\subsection{Description of the heating system}

The heating system investigated in this study is presented in Figure 1. It consists of an $8.9 \mathrm{~kW}$ heat pump connected to a $109.6 \mathrm{~L}$ vertical cylindrical TES tank. The fluid used in this heating system was water. On the left side of the sketch, the charge operation can be observed, where cold water from the bottom of the tank passes through the heat pump. After being heated, the water enters into the tank through the inlet on the top of the tank. On the right side of the sketch, the discharge operation is presented, where cold water enters the bottom of the tank while the hot water from the top of the tank is discharged. The tank used in this heating system was made of steel with a wall thickness of $2.5 \mathrm{~mm}$ at the sides of the tank and a wall thickness of $3 \mathrm{~mm}$ at the top and the bottom of the tank. 


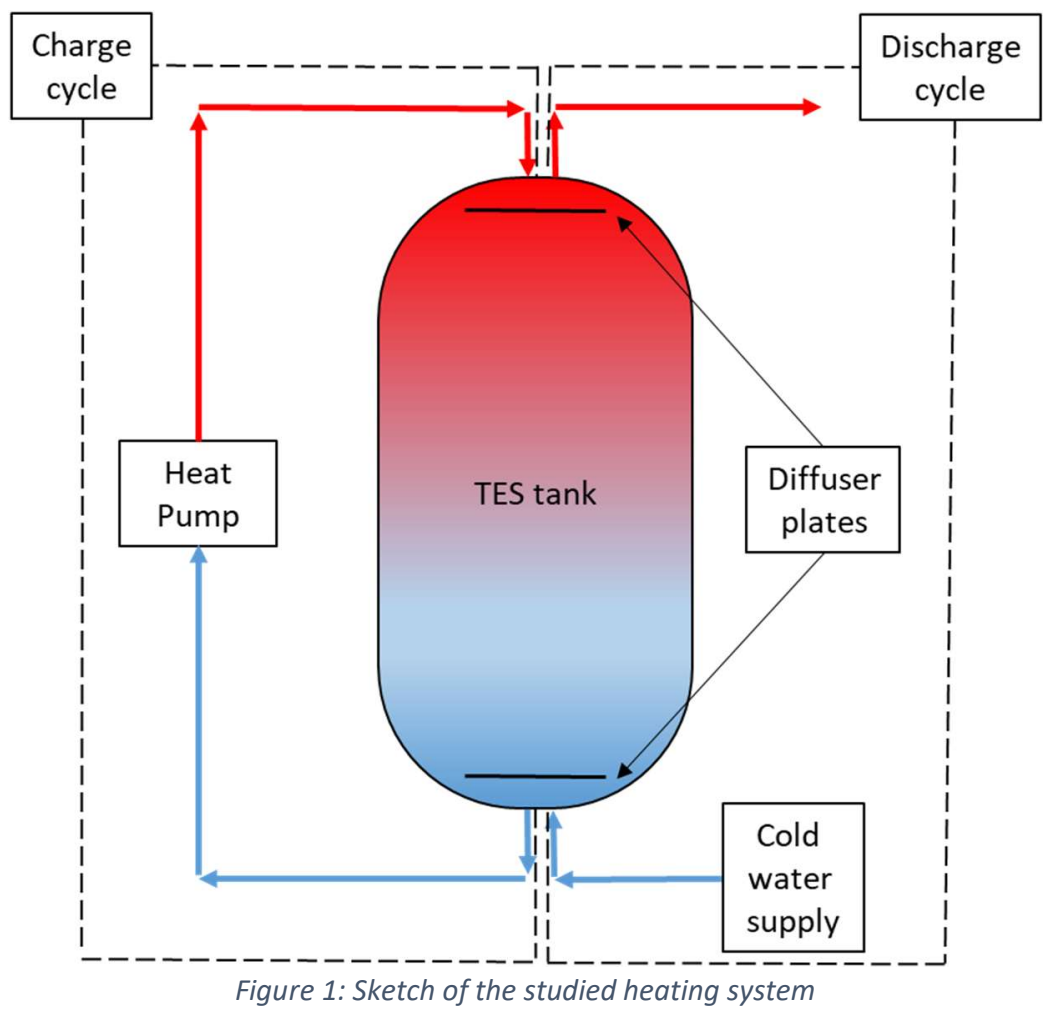

\subsection{Description of the Charge/Discharge operation}

Two different charge and discharge modes were investigated. The difference between the two modes was the flow rate in the tank loop and consequently the duration of the charge and discharge operation. Mode 1 had a flow rate of $0.24 \mathrm{~kg} / \mathrm{s}$ and Mode 2 had a flow rate of $0.12 \mathrm{~kg} / \mathrm{s}$. In the results presented in this paper, Mode 1 is referred as "high" case and Mode 2 as "low" case. These two flow rates were applied to all tested tank geometries.

The primary interest of this paper was the thermal stratification in the tank. Therefore, the heat pump was not explicitly modelled in the CFD model. The calculation of the performance of the heat pump was done using the online GEA selection program VAP (GEA-Group, 2019) in combination with the software CoolPack version 1.5.0 (IPU, 2019). For the calculations, a compressor from GEA Bock type EX-HG34P/315 having R600a as refrigerant was used, having constant evaporating temperature of $T_{0}=5^{\circ} \mathrm{C}$, with superheat at $20 \mathrm{~K}$ and sub-cooling at $10 \mathrm{~K}$. Since the heat pump's characteristics were known, calculations were performed and the temperature increase of water passing through the heat pump was determined for a given volume flow rate. It was assumed that the inlet temperature of the heat pump was equal to the outlet temperature of the tank and that the outlet temperature from the heat pump was equal to the inlet temperature of the tank. That way, water from the tank outlet would pass through the heat pump and after being heated up, would return to the inlet of the tank without having any thermal losses from the pipes. Figure 2 shows the inlet temperature of the tank as a function of the outlet temperature of the tank based on heat pump operation. A UDF was written in ANSYS Fluent in order to create the temperature profile for the inlet of the tank. The UDF found the area-averaged temperature at the outlet of the tank and then increased it based on the curve presented in Figure 2. Afterwards, the UDF applied 
the obtained temperature to the inlet of the tank. The temperature range of the charge operation was from $35^{\circ} \mathrm{C}$ to $75.3^{\circ} \mathrm{C}$.

For the discharge operation, cold water of $35{ }^{\circ} \mathrm{C}$ was supplied at the bottom of the tank and hot water located at the top of the tank was discharged. The temperature range of the discharge operation was from $75.3^{\circ} \mathrm{C}$ to $60^{\circ} \mathrm{C}$.

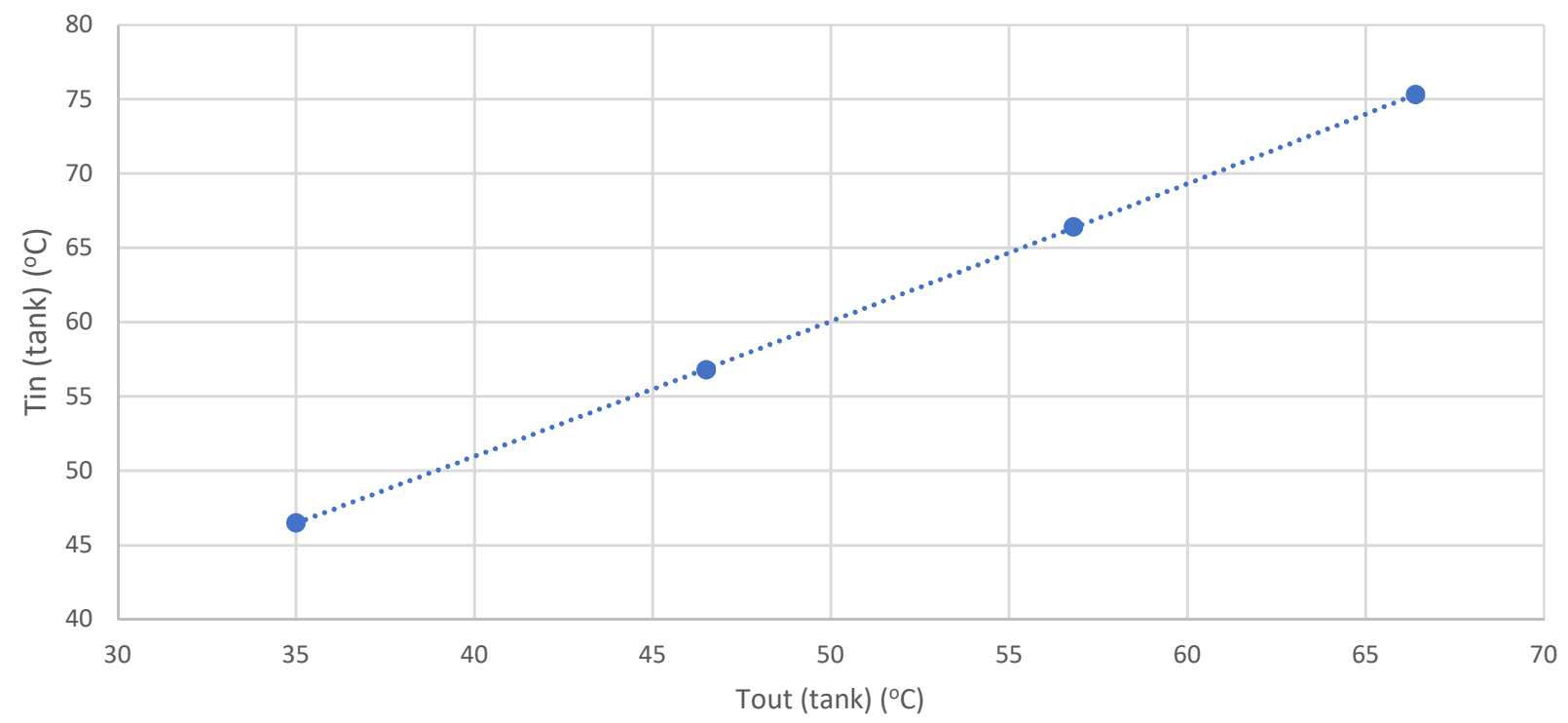

Figure 2: Correlation between tanks' inlet and outlet temperature based on heat pump operation

\subsection{Control of the Charge/Discharge cycles}

In order to make a fair comparison between the various solutions tested, a control method was developed, which stopped the simulation (either the charge or the discharge) when the temperature at the inlet/outlet of the tank reached a specific value. The control temperatures were $75.3^{\circ} \mathrm{C}$ and $60^{\circ} \mathrm{C}$ for the charge and the discharge respectively. In this way, the energy content of the tanks at the end of the charge/discharge was almost the same and it was mainly affected by the heat transfer between the water and the tank wall and by mixing. Therefore, the charge/discharge duration of the tested solutions was not exactly the same.

\subsection{Parameters under consideration}

Various parameters were tested in order to evaluate their effect on the thermal stratification in the tank during charge and discharge.

\subsubsection{Tank dimensions}

In order to examine the effect of the dimensions of the tank on the COP of the system, three different tank geometries were simulated with different height/diameter ratios. The volume of the tanks was kept constant in all three scenarios. The investigated tank dimensions are presented in Table 1. 


\begin{tabular}{cccc}
\hline & Tank 1 & Tank 2 & Tank 3 \\
\hline Height to diameter & 3.64 & 2 & 1 \\
ratio, $\mathbf{h} / \mathbf{d}$ & 1.25 & 0.82 & 0.52 \\
Height, $\mathbf{h}(\mathbf{m})$ & 0.34 & 0.41 & 0.52 \\
Diameter, $\mathbf{d}(\mathbf{m})$ & 109.6 & 109.6 & 109.6 \\
Tank volume, $\mathbf{V}(\mathrm{L})$ & & & \\
\hline
\end{tabular}

\subsubsection{Diffuser design}

In order to assess the impact of the diffuser design on thermal stratification in the tank, four different diffuser designs were examined. One diffuser was placed at the inlet and a second, identical one, at the outlet of the tank. The inlet/outlet was located in the middle of the top and bottom heads of the cylindrical tanks. In order to keep the effect of the diffuser comparable among all cases, the dimensions of the diffusers were expressed as dimensionless ratios. The investigated designs are presented in Table 2. Each tank geometry was tested for all the diffuser designs.

Table 2: Tested tank diffusers

\begin{tabular}{ccccc}
\hline & Scenario A & Scenario B & Scenario C & Scenario D \\
\hline Description & $\begin{array}{c}\text { No diffuser } \\
\text { present inside } \\
\text { the tank }\end{array}$ & $\begin{array}{c}\text { Single plate } \\
\text { diffuser (large) }\end{array}$ & $\begin{array}{c}\text { Single plate } \\
\text { diffuser (small) }\end{array}$ & $\begin{array}{c}\text { Perforated single plate } \\
\text { diffuser having the same } \\
\text { distance from } \\
\text { inlet/outlet }(\mathbf{m})\end{array}$ \\
$\begin{array}{c}\mathbf{d}_{\text {diffuser }} / \mathbf{d}_{\text {tank }} \\
\text { Inlet/outlet } \mathbf{d}_{\text {pipe }}(\mathbf{m})\end{array}$ & - & 0.01 & 0.01 & 0.01 \\
\hline
\end{tabular}

It should be noticed that all the diffusers were placed very close to the inlet/outlet of the tank, in order to minimize the inlet region where mixing of water occurs. A visualisation of the diffuser designs is presented in Figure 3.

"Scenario D" had a $2 \mathrm{~mm}$ thick plate with a porosity of 5\%, corresponding to 66 holes of a diameter 0.0075 $\mathrm{m}$ spread uniformly over the plate area. It also has to be stated that "Scenario D" had a small nonperforated cyclic region with a diameter of $0.044 \mathrm{~m}$ in front of the inlet, in order to block the direct inlet of water jet in the tank. The red area in Figure 3(c), represents the perforated part of "Scenario D" plate which had an outer diameter of $0.276 \mathrm{~m}$. 


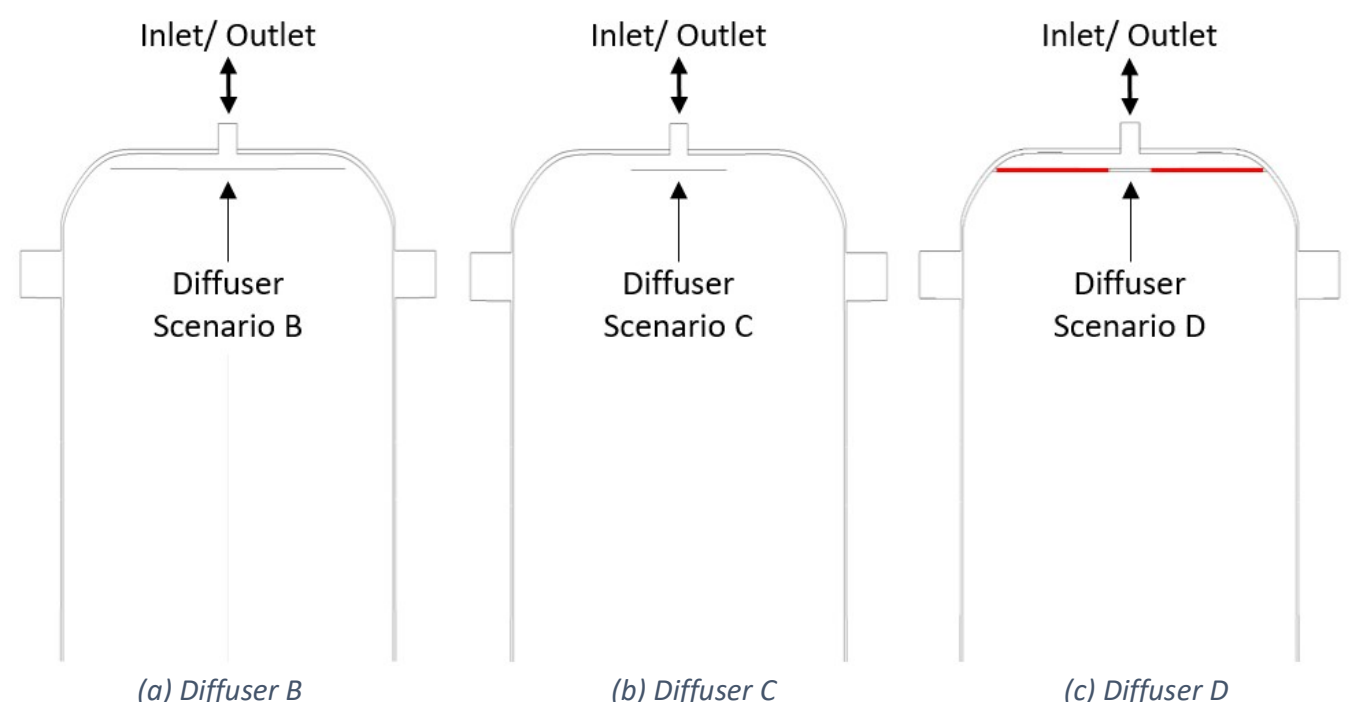

Figure 3: Diffuser designs mounted on the tank top

\subsubsection{Tank wall material}

Lastly, the effect of thermal conductivity of the material on thermal stratification in the tank was examined. In order to remove the effect of the material, a scenario was created using a tank with a hypothetical material having zero specific heat capacity and thermal conductivity, meaning that there was no heat transfer between the water and tank wall, no possibility to store heat in the tank walls and no heat loss.

\subsection{CFD Model Description}

In order to choose the right turbulence model in the CFD model, an estimation of the Reynolds number of the investigated cases was done. The calculation was performed both for flow inside the inlet pipe and flow inside the tank using equation (1) (Cebeci et al., 2005):

$$
R e=\frac{\rho \cdot v \cdot L}{\mu}
$$

Where $\rho$ and $\mu$ were density and viscosity of water at a temperature of $60^{\circ} \mathrm{C}$. For the inlet pipe, a Re of 29,371 was found while for the tank a Re of 1,900 was found. It indicates that flow in the inlet pipe is clearly in the turbulence region while flow in the tank is marginally in the laminar region. However, due to the disturbance created by the incoming jet flow and by the diffuser plate, flow in the tank has tendency to be turbulent, therefore a turbulence model is used in the CFD calculations. A transient CFD model was developed on ANSYS Fluent using the SST k- $\omega$ turbulence model because it was considered more appropriate for internal flow in the investigated case. The Boussinesq approximation was used to calculate the buoyancy driven forces and the SIMPLE scheme was used for coupling pressure and velocity. Turbulent kinetic energy and specific dissipation rate were discretized using the "first order upwind" scheme while momentum and energy equations were discretized using the "second order upwind" scheme.

Due to the low complexity of the model, and based on previous experience, an axisymmetric 2D model was considered appropriate for the simulations. In addition, due to the symmetrical geometry, only half 
of the tank was modelled, using an appropriate boundary condition. The simulated geometries are illustrated in Figure 4.

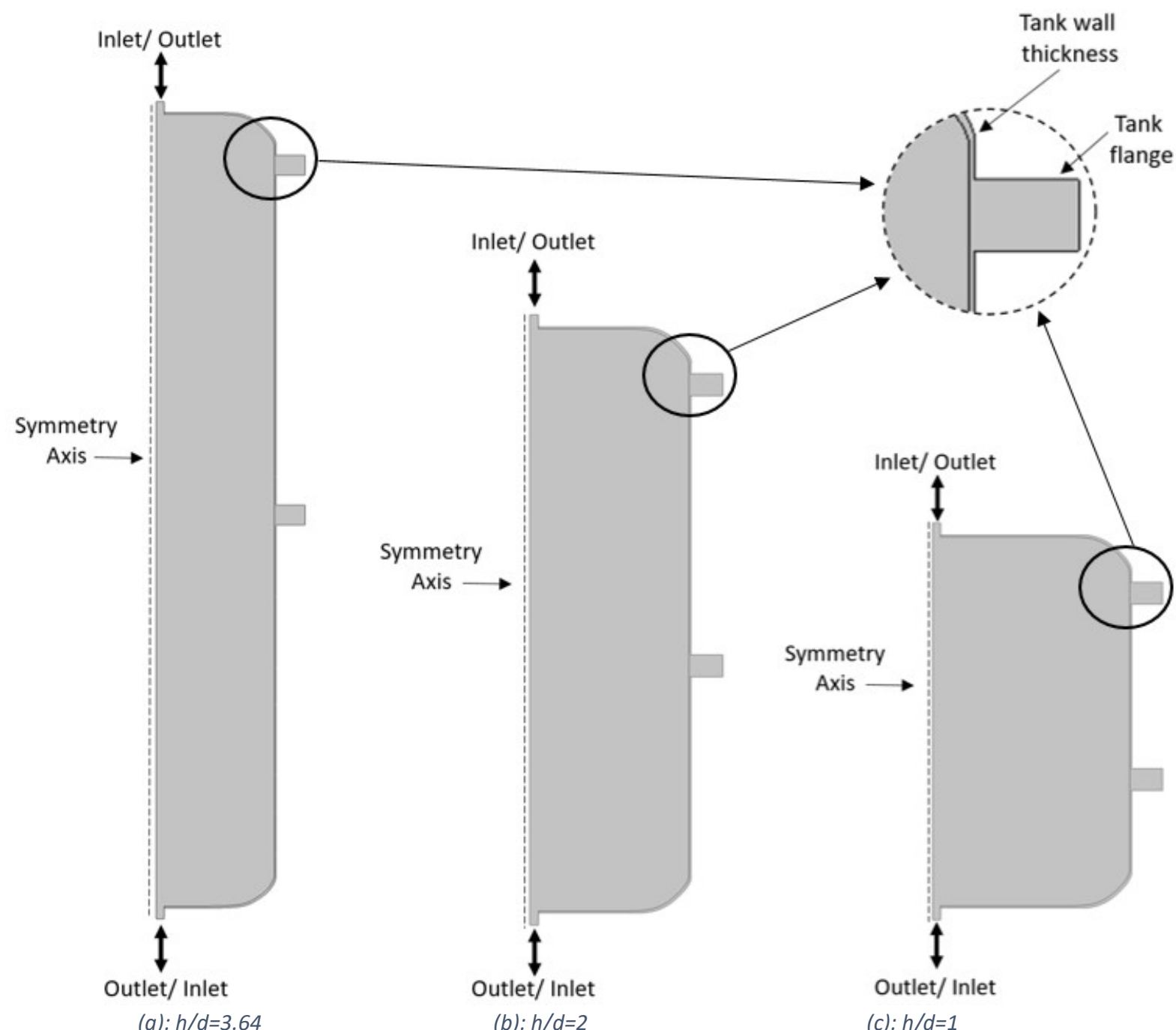

Figure 4: Geometries of the modeled tanks

Quadrilateral dominant mesh was used to discretize the modelled tanks. In the cases where a diffuser was present inside the tank, a mesh refinement was done around the diffuser area. The mesh size was determined after performing a sensitivity analysis using three different mesh densities. The result of the analysis is presented in Figure 5 . There is a notable difference in calculated temperatures with an increase of cell count from 15,000 to 25,000 . While further increase of the cell count to 35,000 does not significantly change the result. Therefore, the result with 25,000 cells is considered grid independent. The mesh scheme with 25,000 cells was used in the CFD simulations. In the mesh scheme, the maximum cell 
width was $0.004 \mathrm{~m}$ and the minimum was $0.001 \mathrm{~m}$. As an example, the mesh of Case "Tank $1 \mathrm{~A}$ " is presented in Figure 6Error! Reference source not found..

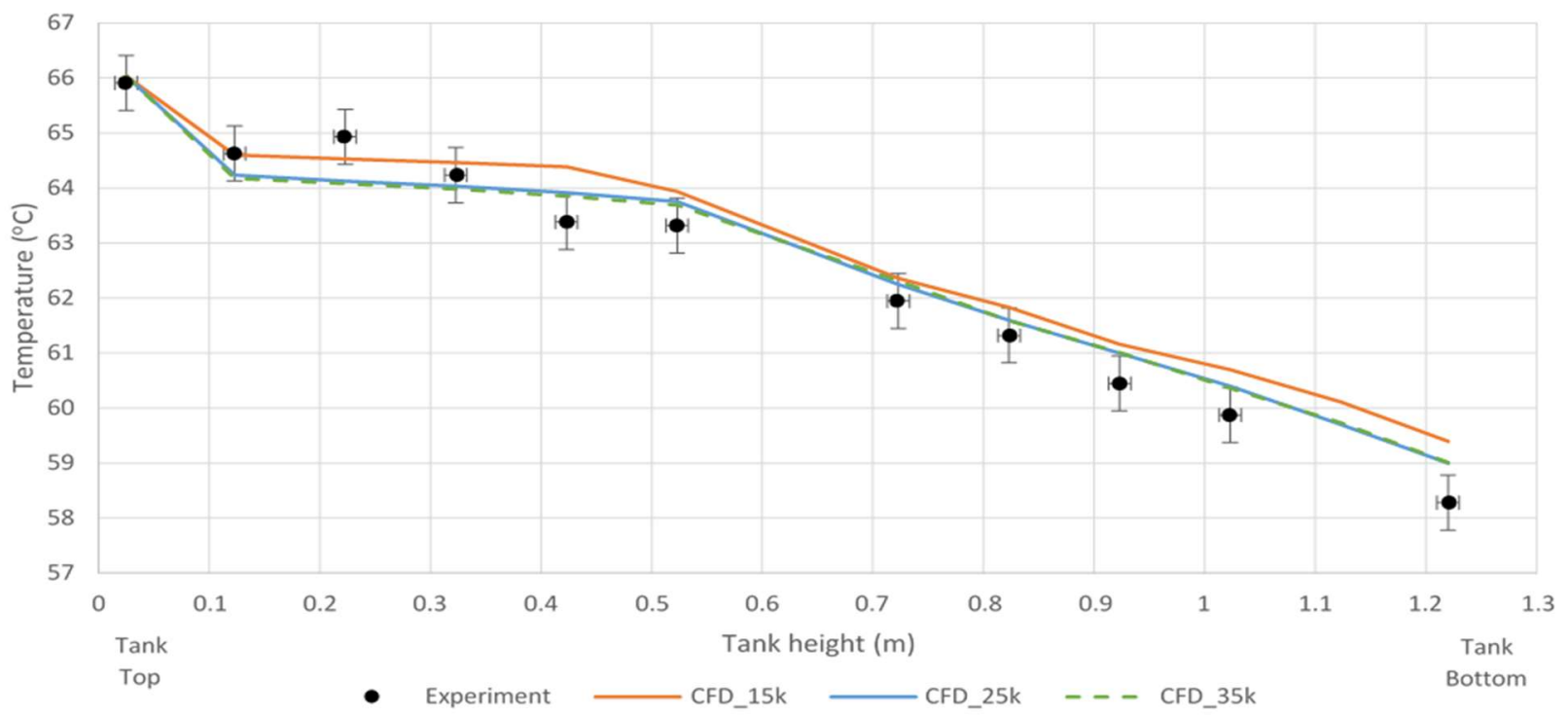

Figure 5: Results of mesh sensitivity analysis - Temperature inside the tank at the end of charge operation

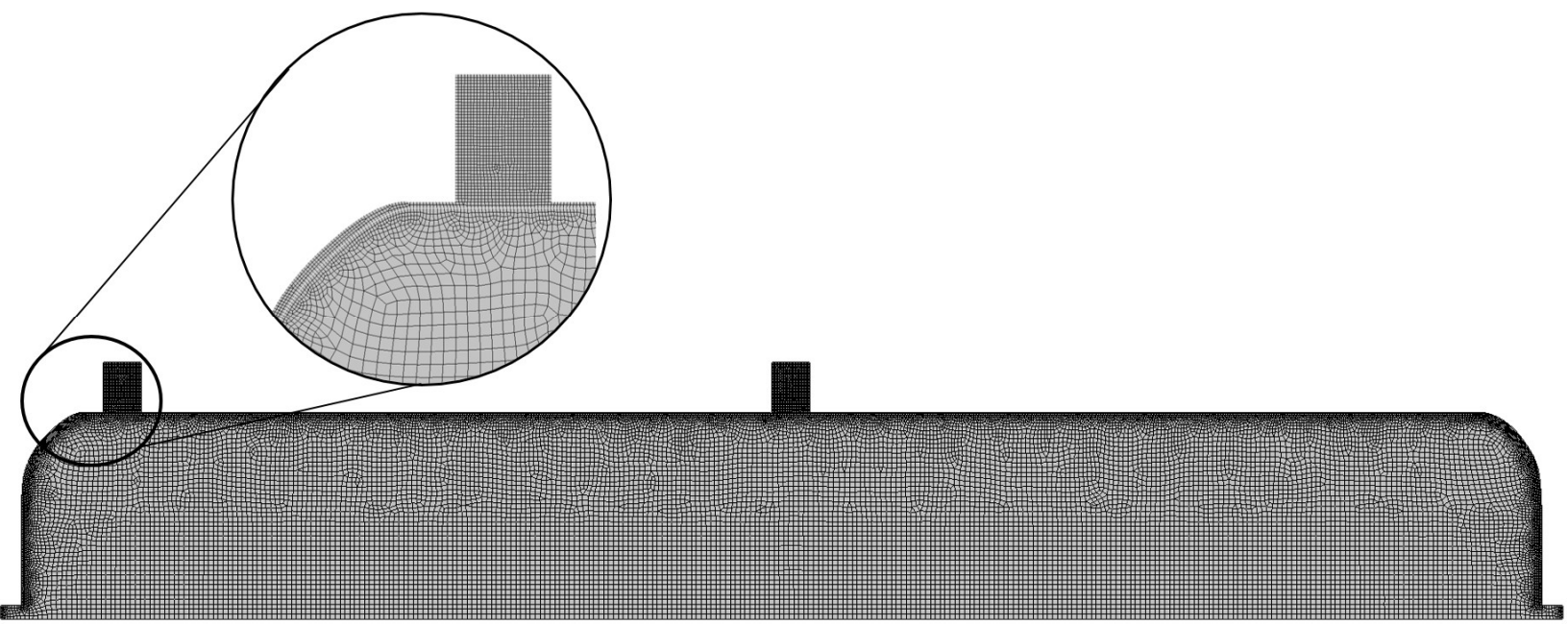

Figure 6: Created mesh of simulated geometry for case "Tank $1 A$ "

The time step used in the simulation was $0.5 \mathrm{~s}$, which is determined based on the Courant-FriedrichsLewy (CFL) condition where the selection of the time step should depend on the mesh size and the velocity (Cebeci et al., 2005):

$$
C F L=\frac{|v| \cdot \Delta t}{\Delta x} \leq 1
$$

The average velocity inside the tank was found around $0.002 \mathrm{~m} / \mathrm{s}$ due to the presence of the diffuser, so a time step of $0.5 \mathrm{~s}$ was considered appropriate. 
The tank was insulated with a heat loss coefficient of $0.22 \mathrm{~W} / \mathrm{m}^{2} \mathrm{~K}$ and was placed in an ambient temperature of $20^{\circ} \mathrm{C}$. Thermal bridges, for instance caused by the pipe connections, were neglected. The inlet of the tank was modelled as a "velocity-inlet" and the outlet as an "outflow".

Regarding the charge operation, in order to be able to perform a direct comparison between the different tank designs, it was considered essential to have the same energy content at the start of the simulations. For this reason, a scenario of a uniform temperature was created, where both the water and the steel walls of the tank had a temperature of $35^{\circ} \mathrm{C}$. This scenario was used for all the simulated cases.

In the discharge cases, the temperature profile inside the tank at the end of the charge was used as an initial condition, so it was different for every simulated case. However, due to the controls applied to the inlet temperature, the energy content of the tanks were similar for all cases at the end of the charge operation. Before starting the discharge, there was a 2-minute waiting time.

\subsection{Calculation of the system COP}

In order to evaluate the performance of each system, the COPs were calculated. The total average COP of the systems was calculated in two stages.

$$
\text { COP during charge: } \operatorname{COP}_{1}=\frac{\text { Total heat in the tank by end of the charg }}{\text { Total electricity consumption for heat pump }}
$$

$$
\text { COP during charge and discharge: } \mathrm{COP}_{2}=\frac{\text { Total tapped energy }}{\text { Total electricity consumption for heat pump }}
$$

In order to calculate the "Total heat in the tank by the end of charge", equation (5) was used, which finds both the heat stored in the water and the heat in the steel wall of the tank:

$$
Q=\left[m \cdot C_{p} \cdot\left(T_{\text {final }}-T_{\text {initial }}\right)\right]_{\text {water }}+\left[m \cdot C_{p} \cdot\left(T_{\text {final }}-T_{\text {initial }}\right)\right]_{\text {steel }}
$$

In order to calculate the "Total tapped energy", equation (6) was used, which finds the energy removed from the tank during discharge:

$$
Q=\frac{\rho \cdot C_{p} \cdot \Delta T \cdot V}{1 k W h(=3.6 \mathrm{MJ})} \cdot 1 k W h
$$

The total electricity consumption of the heat pump was estimated using the equation of heat pump's COP:

$$
C O P=\frac{Q_{C}}{W}
$$

The COP of the heat pump depends on the temperature of the water entering the heat pump. The correlation of the water temperature and COP of the heat pump is presented in Figure 7. 


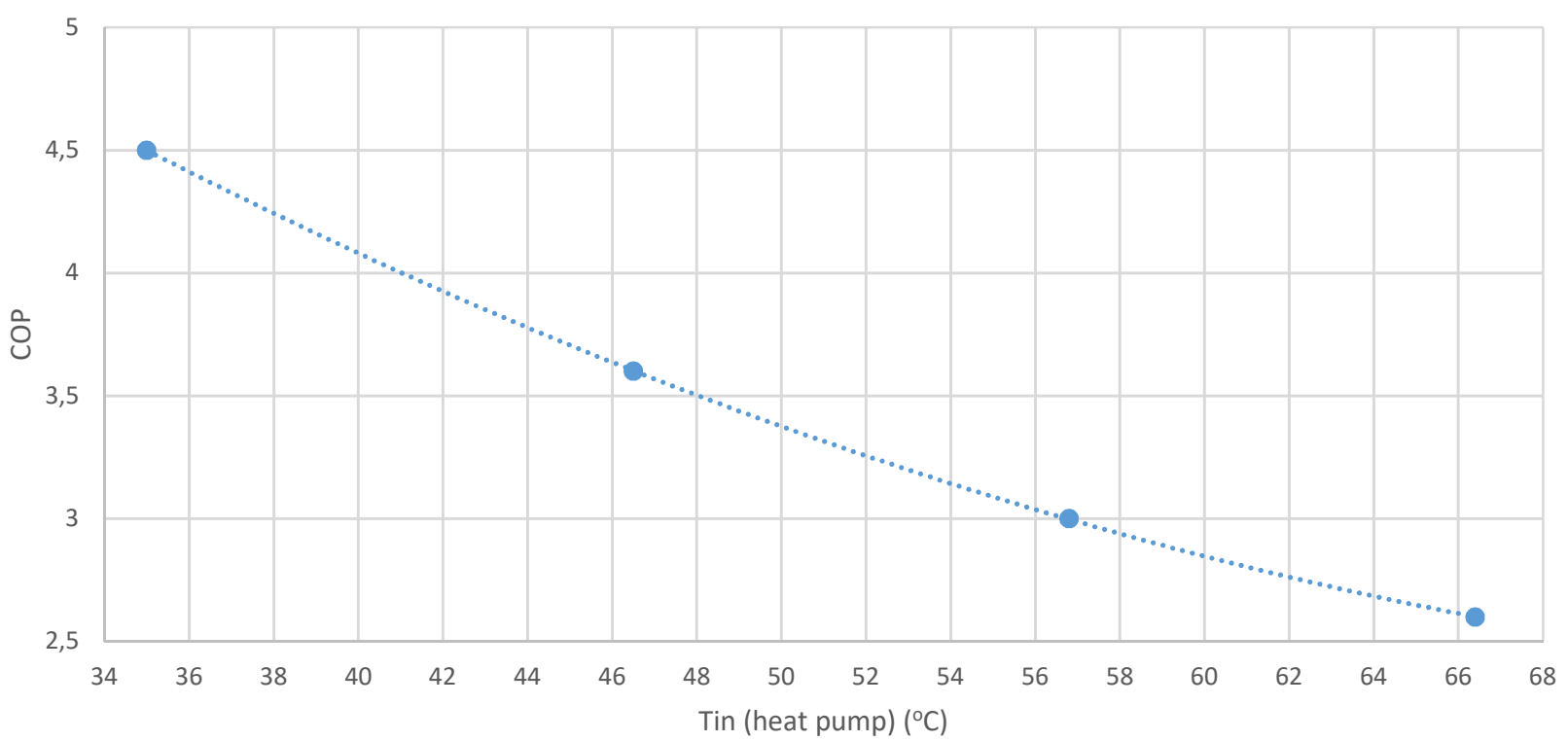

Figure 7: Correlation between water temperature entering the heat pump and heat pump's COP (GEA-Group, 2019)

\section{Validation of CFD model}

\subsection{Description of experiment}

Initially, the CFD model was validated against experimental data. The experiment was performed as part of the "Isolated System Energy Charging (ISEC)" project at Danish Technological Institute. The tested system consisted of two storage tanks connected to a pump and an electrical heating element. The tanks and the pipes used in this experiment were not insulated. The fluid used in the system was water. The system was operated by charging one of the tanks and at the same time discharging the second tank. That would lead to a constant pump and heating element operation.

The temperature of the storage tanks was measured at the outside of the tank using T-type thermocouples, which had an accuracy of $0.5 \mathrm{~K}$. Twelve thermocouples were placed on the tank wall having a $10 \mathrm{~cm}$ interval. The temperature of the thermocouple placed at the tank height $0.6 \mathrm{~m}$ was not included in the results as it was very close to the tank flange and thus the measurement was considered unreliable. Inside the tank, the temperature was also measured, but only at the tank height of $0.1 \mathrm{~m}$. In order to find the temperature in the tank during charge and discharge operation, the temperature measurements on the tank wall were corrected using the temperature measured in the tank. For measuring the flow rate, two "Kamstrup Multical 62-Ultraflow 24" flowmeters with an accuracy of 2\% were used. The first was measuring the flow in the charge loop and the second in the discharge loop. An overview of the system and the measurement equipment is presented in Figure 8 . The operation settings of the experiment are presented in Table 3.

Table 3: Charge and Discharge settings of the experiment

Charge Duration (min)
20

40 


$\begin{array}{ccc}\text { Flow rate }(\mathrm{kg} / \mathrm{s}) & 0.48 & 0.035 \\ \text { Inlet Velocity }(\mathrm{m} / \mathrm{s}) & 1.25 & 0.091 \\ \text { Inlet Temperature }\left({ }^{\circ} \mathrm{C}\right) & \text { Variable } & 16 \\ \text { Ambient Temperature }\left({ }^{\circ} \mathrm{C}\right) & 22 & 22\end{array}$

The temperature at the inlet of the tank during charge operation is presented in Figure 9. This temperature profile was used as input in the CFD model.

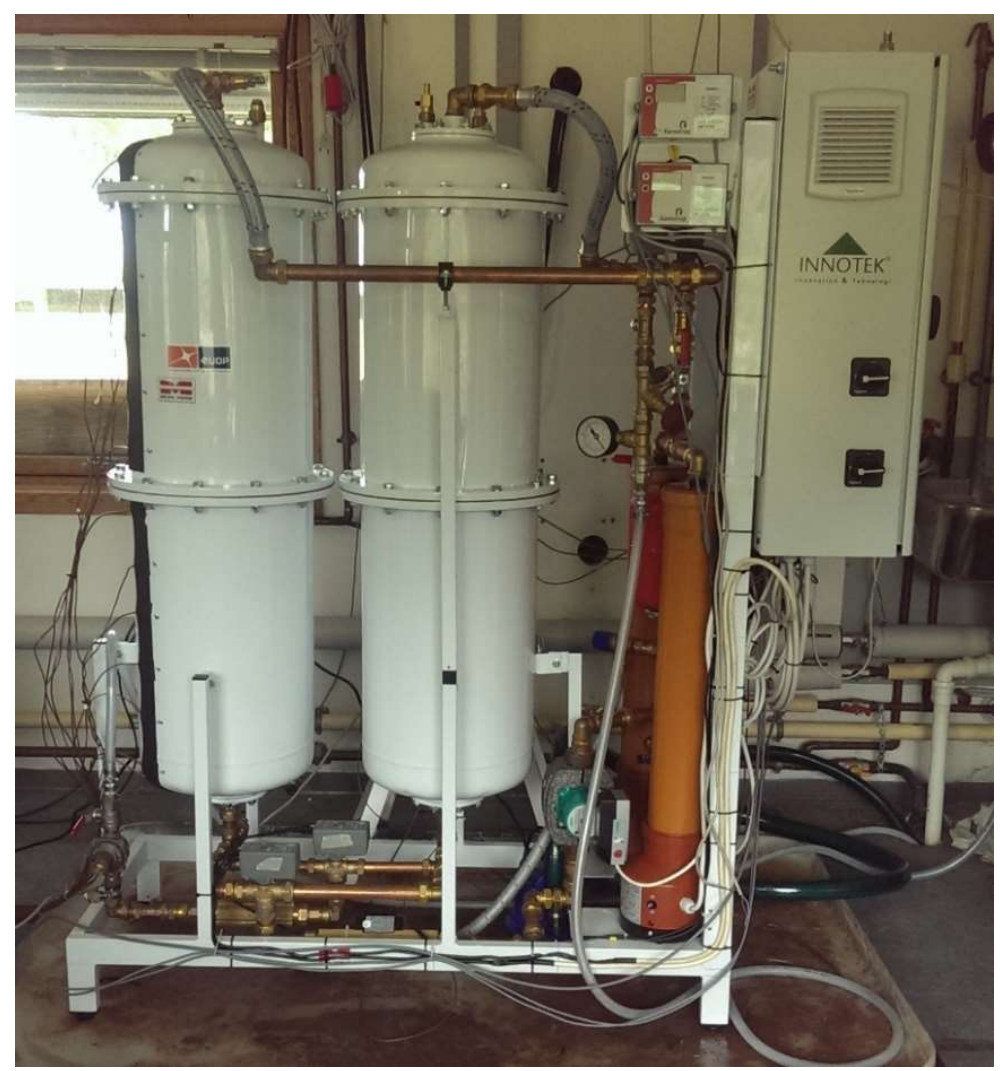

Figure 8: Overview of the setup of the experiment 


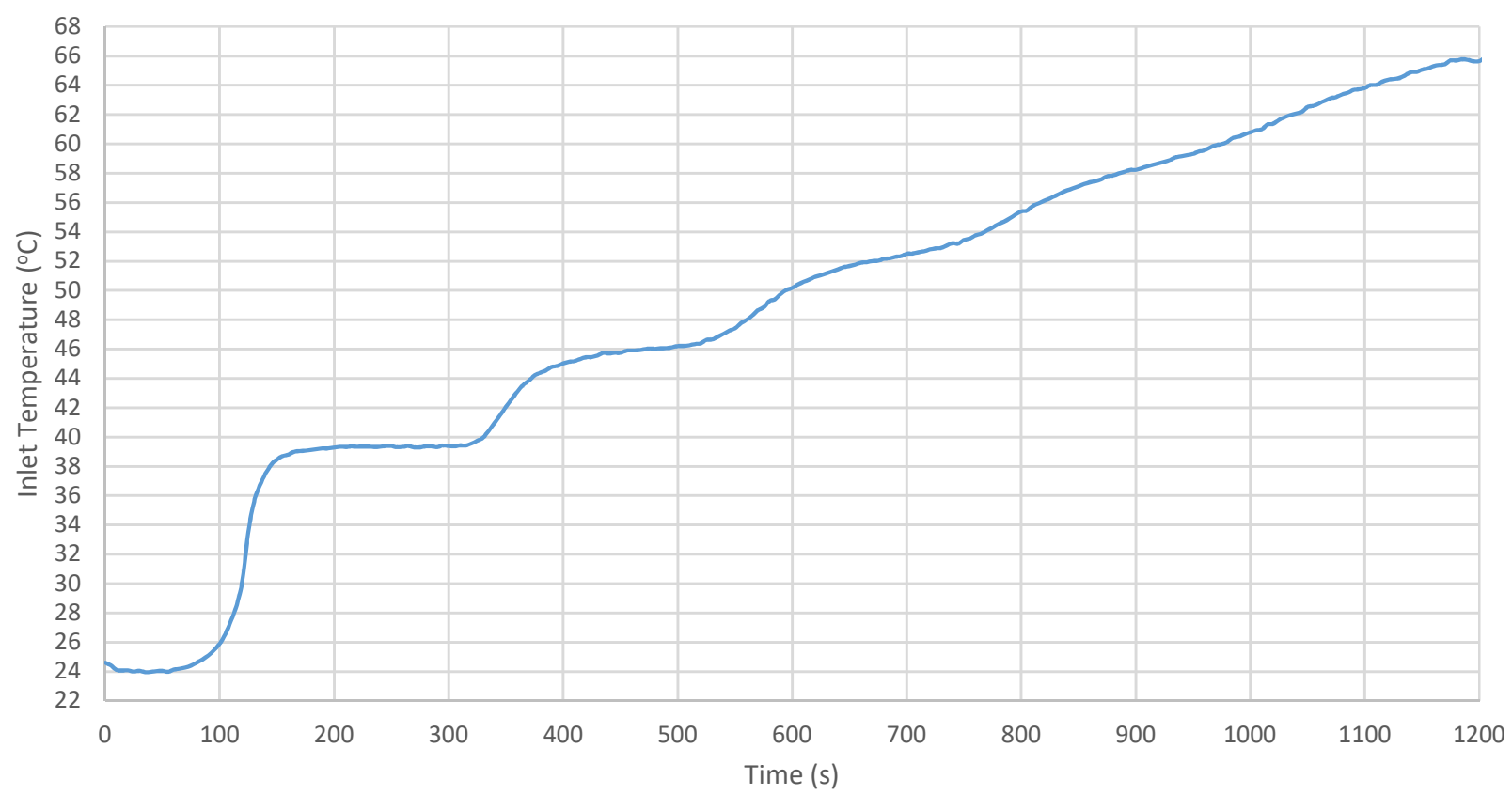

Figure 9: Tank Inlet temperature $\left({ }^{\circ} \mathrm{C}\right)$ during charge operation of the experiment

\subsection{Comparison of CFD calculated and measured thermal stratification in the tank}

In Figure 10 and Figure 11, the temperature in the tank at the end of the charge and the discharge are presented respectively. For both figures, in the horizontal axis, Tank height equal to zero is the top of the tank and Tank height equal to $1.25 \mathrm{~m}$ is the bottom. The dots represent the corrected temperature inside the tank measured by the thermocouples, and the curve represents the temperatures calculated by the CFD model. The relative error between the experimental and the simulated temperatures was calculated using equation (8) and presented in Table 4:

$$
\operatorname{Re}(\%)=\frac{T_{C F D}-T_{E x p}}{T_{E x p}} \cdot 100
$$

Table 4: Relative errors between the experimental values and the CFD calculated values for charge and discharge operation

\begin{tabular}{ccccccccc}
\hline $\begin{array}{c}\text { Tank } \\
\text { height } \\
(\mathrm{m})\end{array}$ & $\begin{array}{c}\text { Measured } \\
\mathrm{T}\left({ }^{\circ} \mathrm{C}\right)\end{array}$ & $\begin{array}{c}\text { Charge Operation } \\
\text { Calculated }\left({ }^{\circ} \mathrm{C}\right)\end{array}$ & $\begin{array}{c}\mathrm{DT} \\
\left({ }^{\circ} \mathrm{C}\right)\end{array}$ & $\begin{array}{c}\text { Relative } \\
\text { error }\end{array}$ & $\begin{array}{c}\text { Measured } \\
\mathrm{T}\left({ }^{\circ} \mathrm{C}\right)\end{array}$ & $\begin{array}{c}\text { Discharge Operation } \\
\text { Calculated }\end{array}\left({ }^{\circ} \mathrm{C}\right)$ & $\begin{array}{c}\mathrm{DT} \\
\left({ }^{\circ} \mathrm{C}\right)\end{array}$ & $\begin{array}{c}\text { Relative } \\
\text { error }\end{array}$ \\
\hline 0.02 & 65.9 & 66.0 & 0.1 & $0.2 \%$ & 56.2 & 55.6 & -0.6 & $-1.1 \%$ \\
0.12 & 64.6 & 64.2 & -0.4 & $-0.6 \%$ & 54.9 & 54.1 & -0.8 & $-1.5 \%$ \\
0.22 & 64.9 & 64.1 & -0.8 & $-1.2 \%$ & 42.8 & 50.1 & 7.3 & $17 \%$ \\
0.32 & 64.2 & 64.0 & -0.2 & $-0.3 \%$ & 25.4 & 29.9 & 4.6 & $18 \%$ \\
0.42 & 63.4 & 63.9 & 0.5 & $0.8 \%$ & 19.1 & 19.5 & 0.4 & $2 \%$ \\
0.52 & 63.3 & 63.8 & 0.4 & $0.7 \%$ & 17.7 & 17.3 & -0.4 & $-2.1 \%$ \\
0.72 & 61.9 & 62.3 & 0.3 & $0.5 \%$ & 15.9 & 15.9 & 0.0 & $0 \%$ \\
0.82 & 61.3 & 61.6 & 0.3 & $0.5 \%$ & 15.8 & 15.7 & -0.1 & $-0.6 \%$ \\
0.92 & 60.4 & 61.0 & 0.5 & $0.9 \%$ & 15.7 & 15.6 & -0.1 & $-0.6 \%$
\end{tabular}




$\begin{array}{lllllllll}1.02 & 59.9 & 60.4 & 0.5 & 0.9 \% & 15.5 & 15.5 & 0.0 & 0 \% \\ 1.22 & 58.3 & 59.0 & 0.7 & 1.2 \% & 15.4 & 15.4 & 0.0 & 0 \%\end{array}$

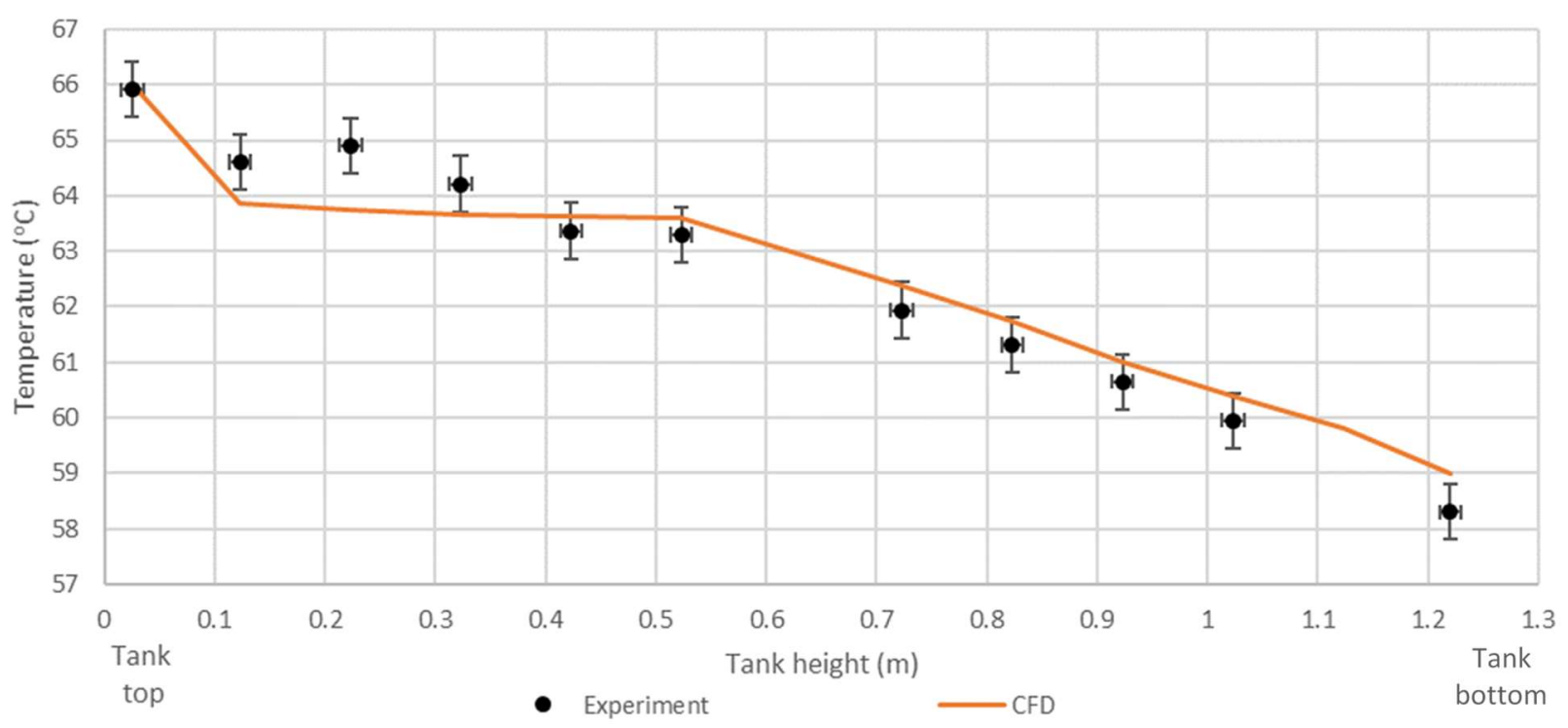

Figure 10: Temperature inside the tank at the end of the charge operation (Tank height=0 is the top of the tank)

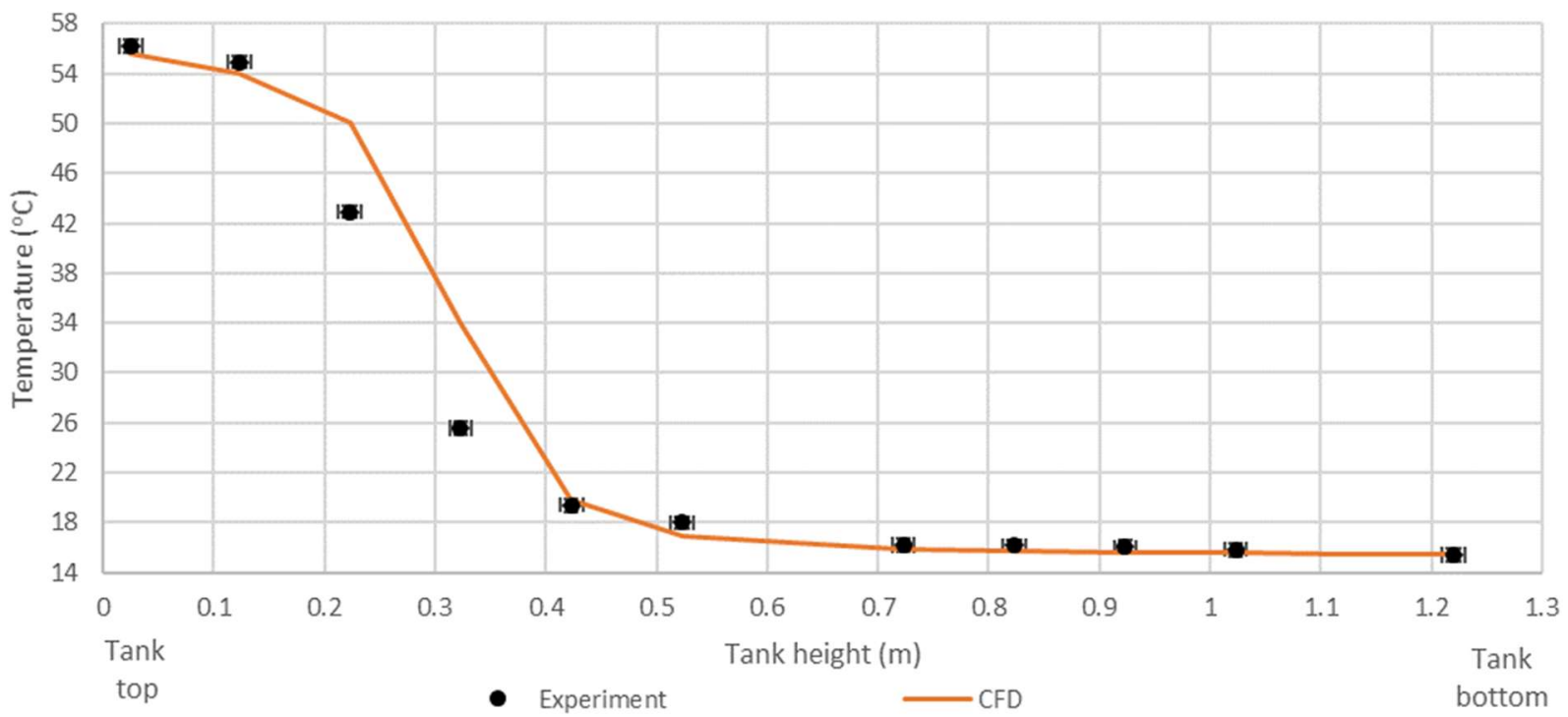

Figure 11: Temperature inside the tank at the end of the discharge operation (Tank height=0 is the top of the tank)

It can be observed that the relative error is small for most of the points indicating validity of the CFD model. The only cases where the relative errors were high (close to 20\%) were P3 and P4 during discharge operation. The reason behind the large error could possibly be inaccurate measurement of sensor locations. The temperature sensors of P3 and P4 were placed outside of the tank close to the tank's flange, which increases the uncertainty of the location measurement. Generally, the relative errors are less than 
$2 \%$ which proves the reliability of the CFD model. The CFD model will be used in further parametric investigations.

\section{Results and discussions}

In Figure 12 to Figure 23, the results of the CFD simulations are presented by a number of curves. A theoretical ideal curve was drawn on each figure in order to compare each case with the ideal scenario. This curve shows how the figure would look like if there were no tank material, no thermal conduction, no heat loss and no mixing inside the tank. The heat storage tank is heated up in 3 heating cycles. In each heating cycle, there is a temperature rise approx. 9.4-11.5K. The ideal curve for charge has a staircase shape because the ideal tank has an uniform temperature and perfect thermal stratification in the tank. The tank will be heated up as plug flow in 3 steps. In a similar way, the ideal curve for discharge has a knee shape.

Due to the heavy insulation of the tank $\left(\mathrm{U}=0.22\left[\mathrm{~W} / \mathrm{m}^{2} \mathrm{~K}\right]\right)$, heat loss of the tank is expected to have a minor impact on the results of the simulations. For this reason, it is deliberately not discussed in the paper.

\subsection{Tank $h / d=3.64$}

In Figure 12, the temperatures at the outlet of the tank during the charge operation can be seen. The "ideal case", which has the highest degree of stratification, has a staircase shape. However, the result shows that, none of the simulated cases was similar to the "ideal case". That means that the obtained results were affected by mixing and thermal conduction. Comparing the simulation results, the effect of mixing can be easily spotted, since all investigated scenarios had similar thermal conduction effect. It can be seen that for the case without a diffuser (Tank 1A high) a high degree of mixing occurs inside the tank (relatively straight curve). On the contrary, the case having a perforated plate diffuser (Tank 1D high), had the most stratified temperature profile, getting the closest to the "ideal case".

Figure 13, presents the tapped energy versus the outlet temperature during discharge operation. It can be observed that the simulation results are very different compared to the "ideal case". The reason is that, in the "ideal case", the whole tank has the same temperature during discharge due to the assumption that there is no vertical thermal conduction in the tank and no mixing with the low-temperature water entering in the bottom of the tank, whereas this is not the case in real-life situations. In addition, in the "ideal case", since tank material is not considered, energy is not stored in the tank walls leading to a lower energy content compared to the simulated cases. It can be observed that "Tank 1A high" most of the tank's volume has a temperature of $69^{\circ} \mathrm{C}$ due to mixing, leading to a "knee" shaped curve. The case with the smallest amount of mixing, Tank 1D, was the one able to provide the highest tapped energy during discharge.

Similar results were obtained for the low flow rate, as it can be seen in Figure 14 and Figure 15. The major difference was found for the tank without a diffuser (Tank 1A). It can be observed that for the low flow rate the curves "Tank $1 \mathrm{~A}$ low", for both charge and discharge, came closer to the other diffuser results, unlike for the high flow rate, due to lower mixing. 
Since the effect of low flow rate on the results was only obvious for the tank without a diffuser (Tank 1A), it was decided not to present the low flow results for the other $h / d$ tested, for space saving purposes.

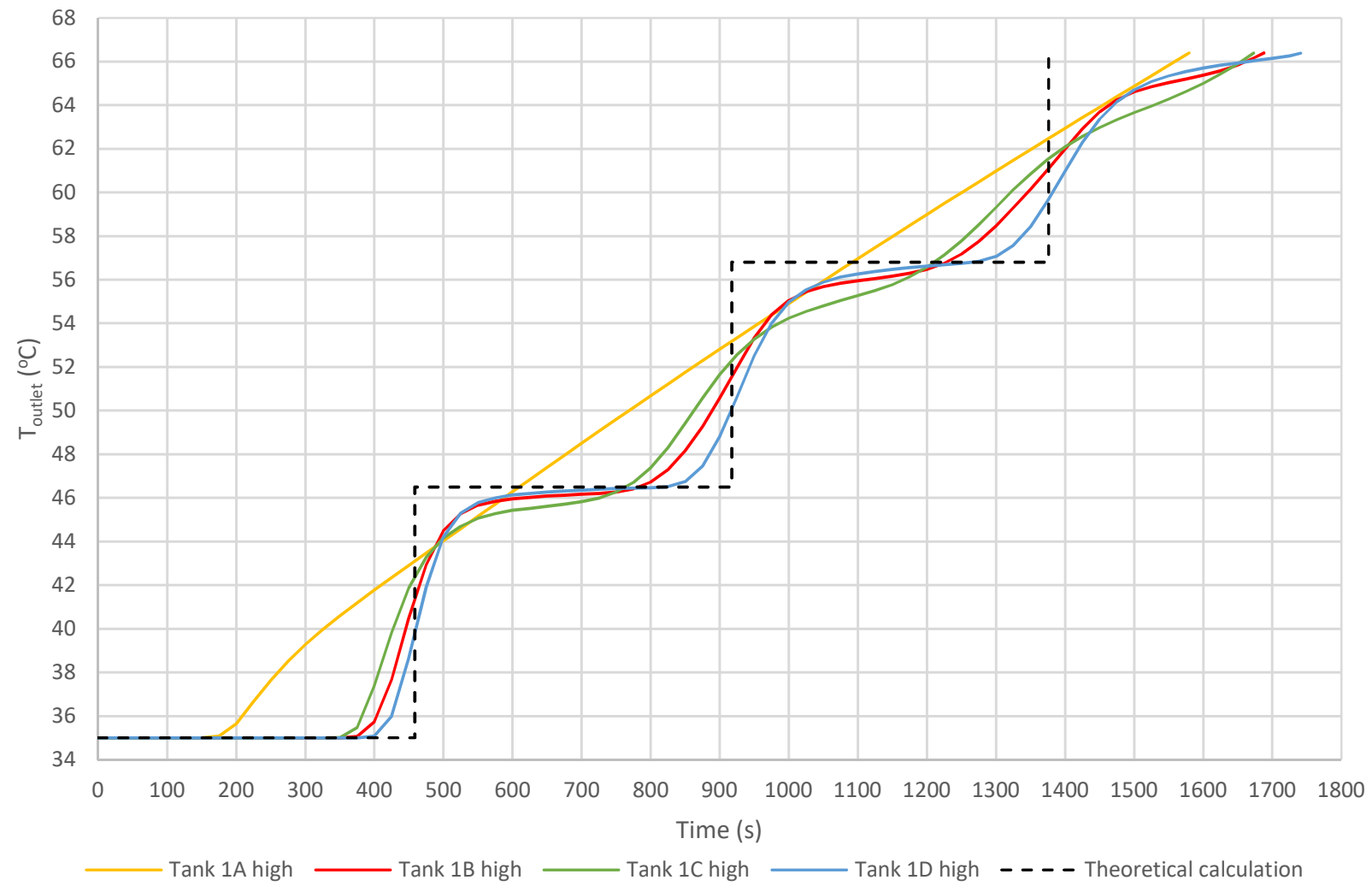

Figure 12: Average temperature at tank outlet during charge - high flow rate $(h / d=3.64)$ 


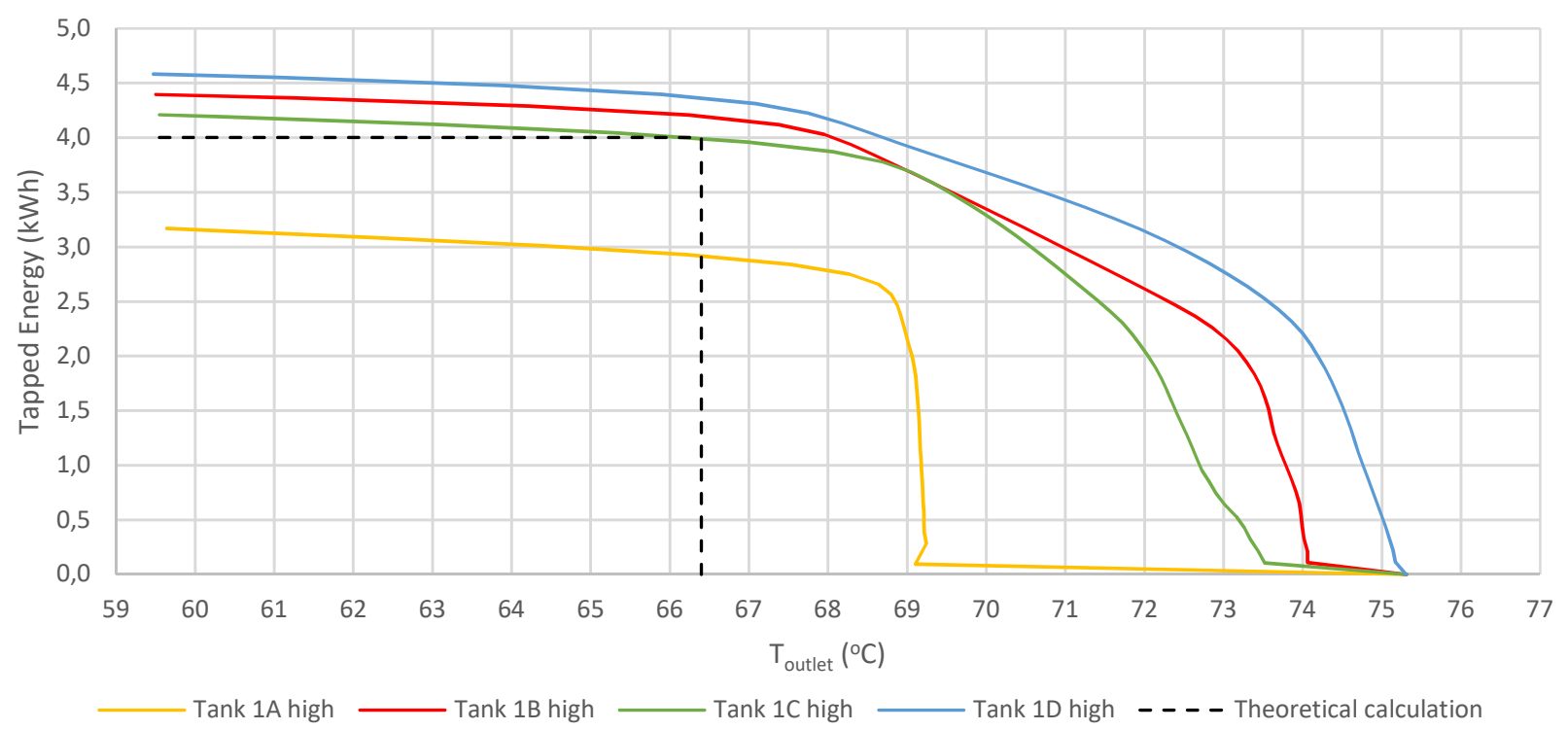

Figure 13: Tapped energy during discharge for a given outlet temperature - high flow rate $(h / d=3.64)$

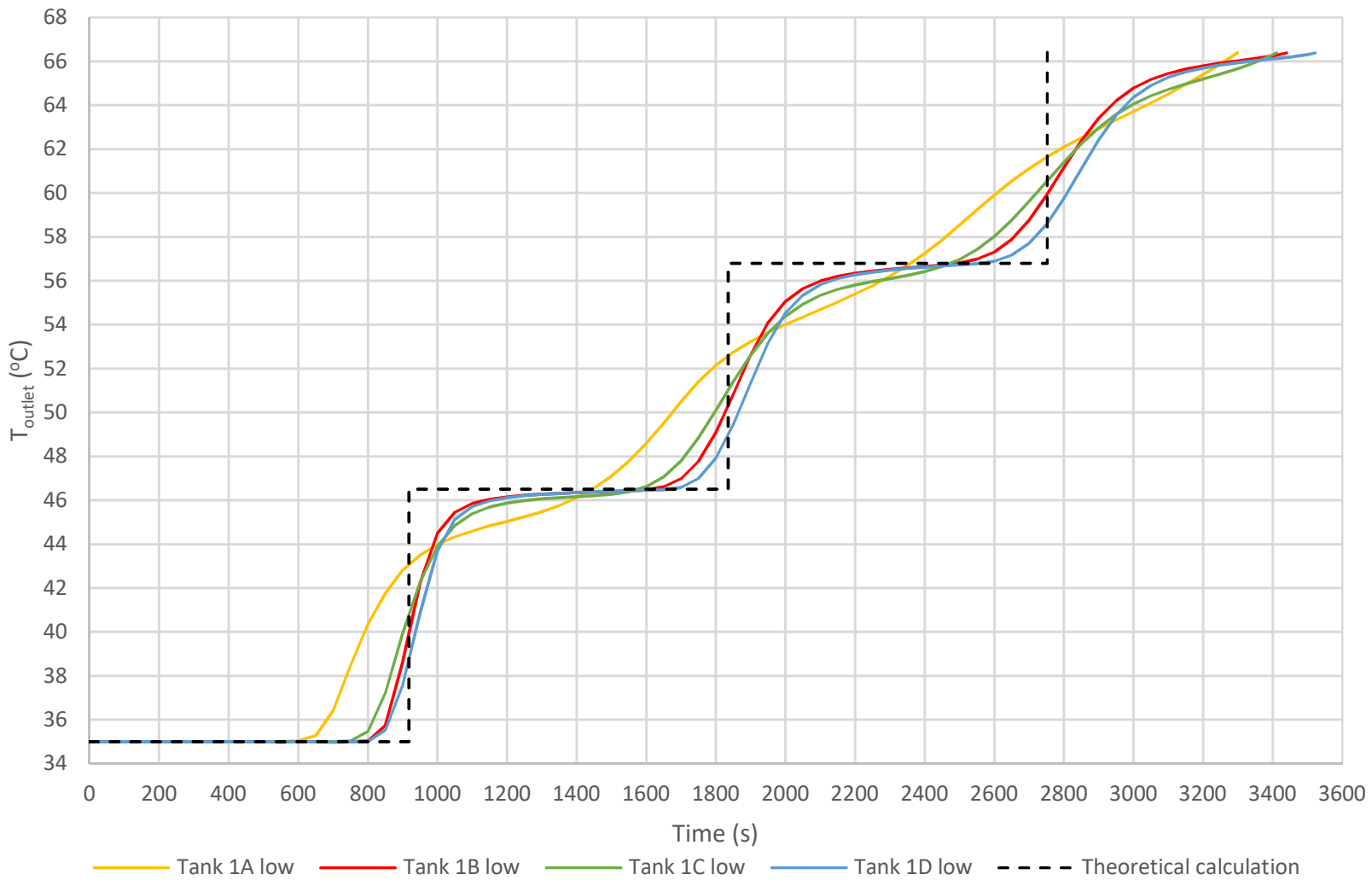

Figure 14: Average temperature at tank outlet during charge - low flow rate $(h / d=3.64)$ 


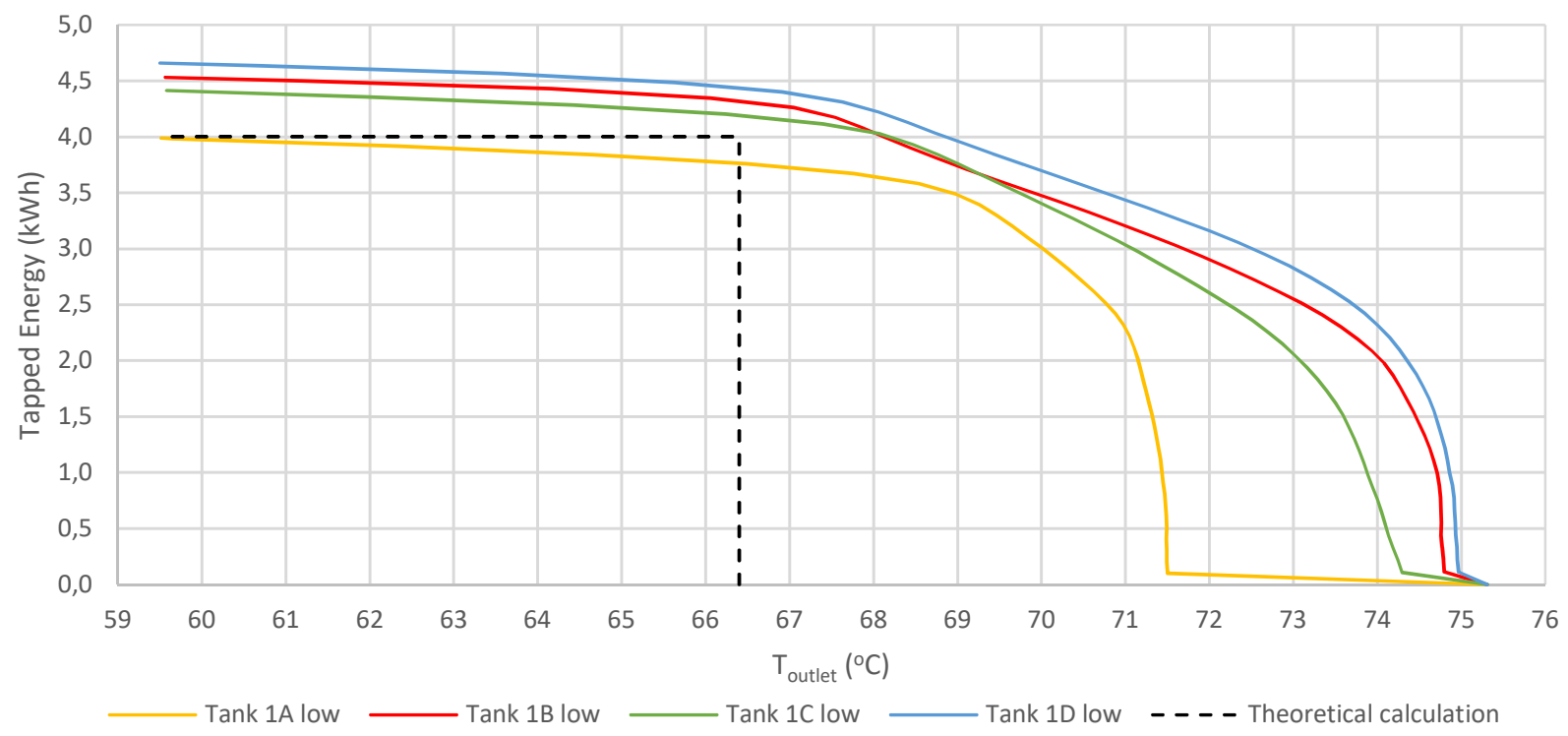

Figure 15: Tapped energy during discharge for a given outlet temperature - low flow rate $(h / d=3.64)$

The effect of the diffuser designs on the mixing in the tank is shown in Figure 16, where the velocity vectors close to the top of the tanks during charge are presented. "Tank $1 \mathrm{~A}$ high" and "Tank $1 \mathrm{C}$ high" have a larger region of high velocities compared to the other two solutions where the high water velocities are limited close to the inlet. It can also be observed that water recirculation zones are developed in all cases except "Tank 1D high". Finally, in all cases, the cooling of water close to the tank walls is visible, creating a down-flow of cooler water with relatively high velocity. Similar flow patterns were seen for the low flow cases but with relatively lower maximum velocity magnitudes.

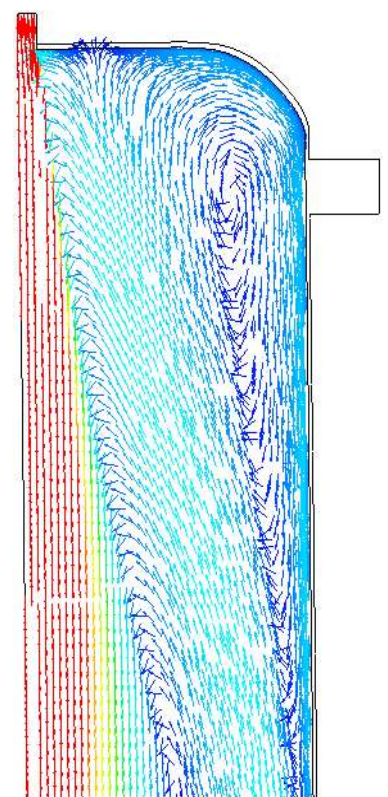

(a): Tank 1A high

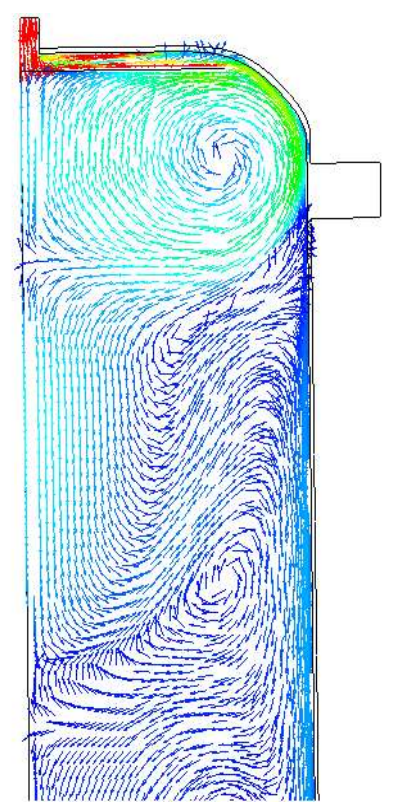

(b): Tank 1B high

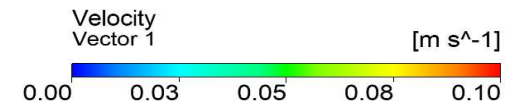

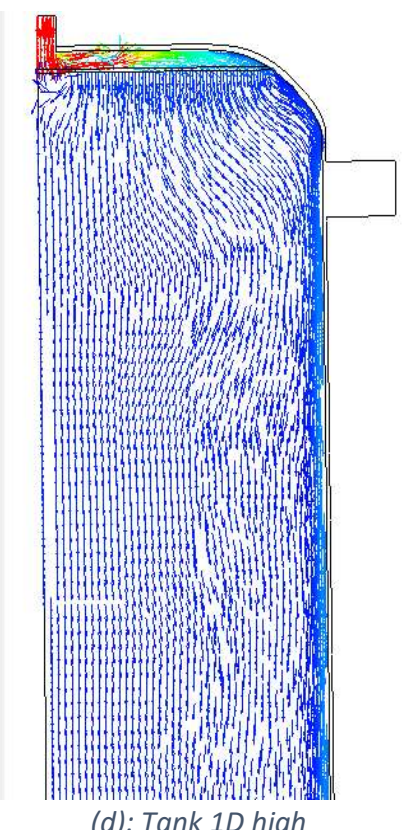

(d): Tank 1D high

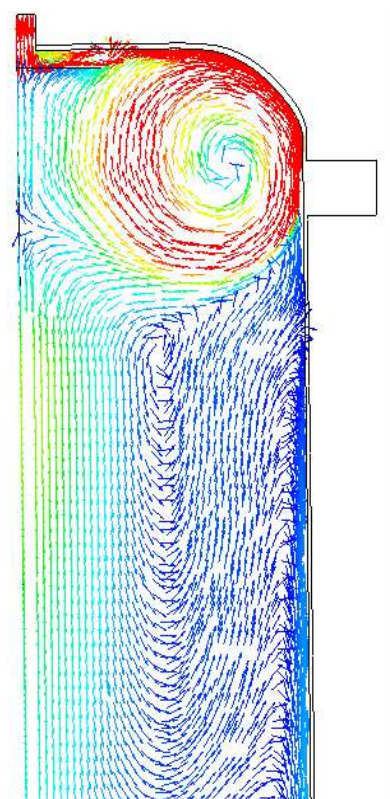

(c): Tank 1C high

Figure 16: Velocity vectors at the top part of the tanks during charge $(h / d=3.64)$ 
The velocity vectors shown in Figure 16 have a direct impact on the temperature contours inside the tank as it can be seen in Figure 17. The results show that the slim-tall tank is able to create thermal stratification in the tank in all cases, regardless of the amount of mixing, due to the high height to diameter ratio of the tanks. This is obvious in Figure 17(a) where, in spite of the high degree of mixing at the top of the tank, relatively large temperature gradient is established at the bottom of the tank. Similar temperature contours were observed for low flow conditions.

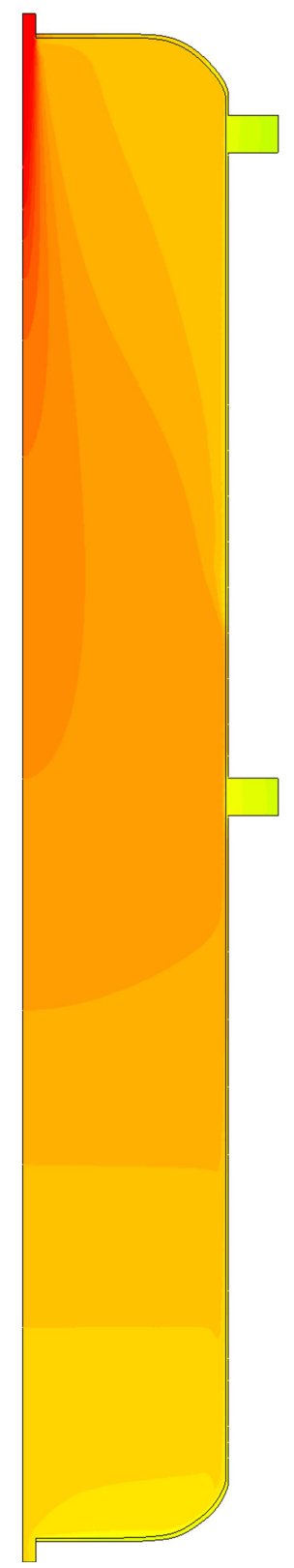

(a): Tank 1A high

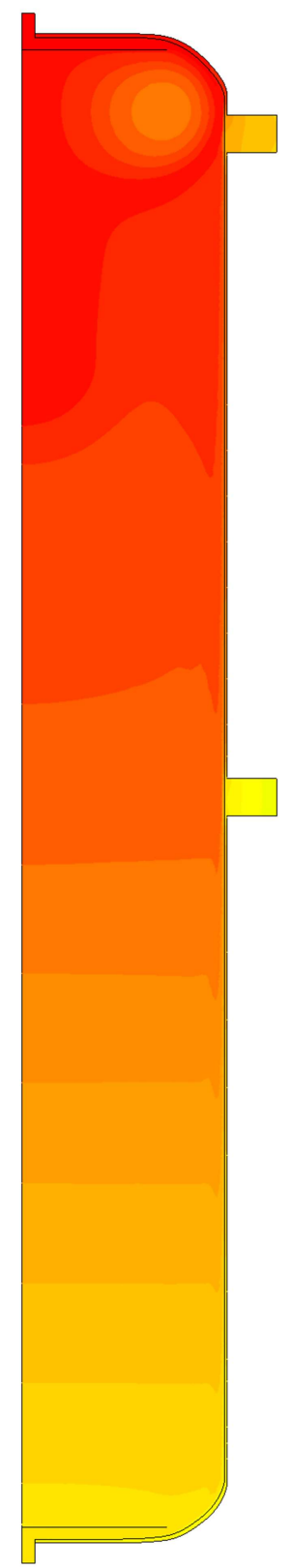

(b): Tank 1B high

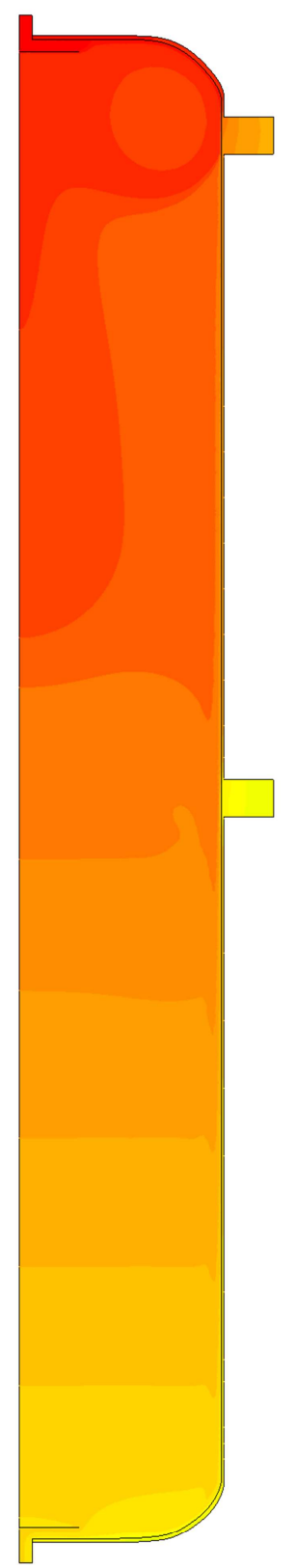

(c): Tank 1C high

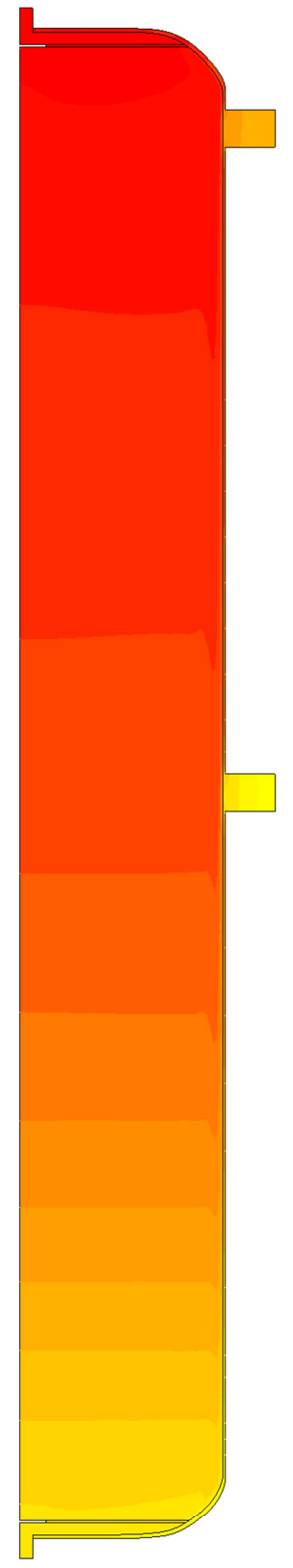

(d): Tank 1D high

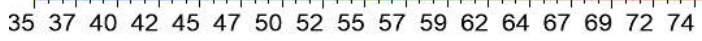

Figure 17: Temperature $\left({ }^{\circ} \mathrm{C}\right)$ contours inside the tanks at the end of charge 
Using equations ( 3 ) and (4), the COP of the system was calculated. The results are presented in Table 5. "Tank 1B high" has the highest $\mathrm{COP}_{1}$ and "Tank 1D high" and "Tank 1D low" have the highest $\mathrm{COP}_{2}$. The reason of the difference is that $\mathrm{COP}_{1}$ takes into account only the temperature at the bottom of the tank but not the entire temperature profile inside the tank. This can also be seen in Figure 17(a), (b) and (c), where although the tanks are thermally stratified in the bottom of the tank, the top of the tank is not stratified. This difference in the temperature profile affects $\mathrm{COP}_{2}$; therefore, it is more accurate to evaluate the performance of the system based on $\mathrm{COP}_{2}$.

Generally, as it was expected since the tank is well-insulated, lower flow rates give higher $\mathrm{COP}_{2}$ due to lower degree of mixing inside the tank. However, the highest $\mathrm{COP}_{2}$ was the same for "Tank 1D high" and "Tank 1D low" proving that when using a diffuser design that minimises mixing, the results become less dependent on the flow rate.

In addition, it can be seen that there is a small difference (around 1\%) between the best performing solutions (Tank 1B and Tank 1D). The maximum difference in COP for the cases having a diffuser was $4.5 \%$, when comparing "Tank $1 \mathrm{C}$ high" and "Tank 1D high", which occurred due to different amounts of mixing inside the tank. Comparing the best performing diffuser cases (Tank 1D) to a case without a diffuser (Tank $1 \mathrm{~A}$ high), an increase of up to $32 \%$ can be obtained in the COP of the system.

As mentioned in the introduction, lower operation temperature gives a higher COP of the heat pump. A good thermal stratification in the tank means that the hot water generated by the heat pump can be stored in the upper part of the tank while water with a lower temperature is stored in the lower part of the tank. Water with a lower temperature entering the heat pump leads to a higher system COP.

During discharge, since the temperature range of the tapped water is from 75.3 to $60^{\circ} \mathrm{C}$ and the water entering the bottom of the tank is $35^{\circ} \mathrm{C}$, it can be expected that due to mixing, it will not be possible to discharge the entire volume of the tank. That will lead to an amount of energy being left in the tank. This residual energy is presented in Table 5 for each simulated scenario. It can be observed that the solutions having the highest COP are the ones having the lowest residual energy in the tank at the end of the discharge. This is also an indication of the amount of mixing in the tank, since lower mixing with the cold water entering the bottom of the tank leads to more energy being tapped and thus less residual energy in the tank.

Table 5: COP and residual energy calculation for $h / d=3.64$ tank for high and low flow rate

\begin{tabular}{cccc}
\hline Case & COP $_{\mathbf{1}}$ & COP $_{\mathbf{2}}$ & Residual Energy (kWh) \\
\hline Tank 1A high & 3.50 & 2.45 & 1.28 \\
Tank 1B high & 3.56 & 3.20 & 0.40 \\
Tank 1C high & 3.55 & 3.09 & 0.53 \\
Tank 1D high & 3.49 & 3.23 & 0.34 \\
Tank 1A low & 3.51 & 2.95 & 0.65 \\
Tank 1B low & 3.51 & 3.22 & 0.35 \\
Tank 1C low & 3.52 & 3.16 & 0.41 \\
Tank 1D low & 3.46 & 3.23 & 0.34 \\
\hline
\end{tabular}




\subsection{Tank $h / d=2$}

Figure 18 and Figure 19 present respectively the charge and discharge operations with a high flow rate for tanks with $\mathrm{a} \mathrm{h/d}$ of 2 . It can be observed that the results are very similar to the ones with $\mathrm{h} / \mathrm{d}=3.64$. Again the simulated results did not come close to the "ideal case" and the best performing solution was the one with a perforated plate as a diffuser (Tank 2D) for both high and low flow rates.

In Table 6, the system COPs are presented. Similar conclusions as for the previous cases can be drawn, with COP being increased up to $65 \%$ by using a diffuser inside the tank. In addition, selecting diffuser " $D$ " over " $\mathrm{C}$ " can increase the COP by up to $6 \%$. These percentages are higher compared to the ones obtained for $h / d=3.64$. The reason is that, since the tank is shorter and has a larger diameter, the influence of the mixing on thermal stratification in the tank is more significant than that in a tall-slim tank. Therefore, a diffuser is necessary to decrease the degree of mixing caused by inlet flows. Similar to the previous results, when using diffuser " $D$ " similar results are obtained for high and low flow rate.

Regarding residual energy, again the cases having the highest COP had the lowest residual energy. It has to be noted though that, due to higher mixing, the residual energy values are higher than the ones for the slim-tall tank.

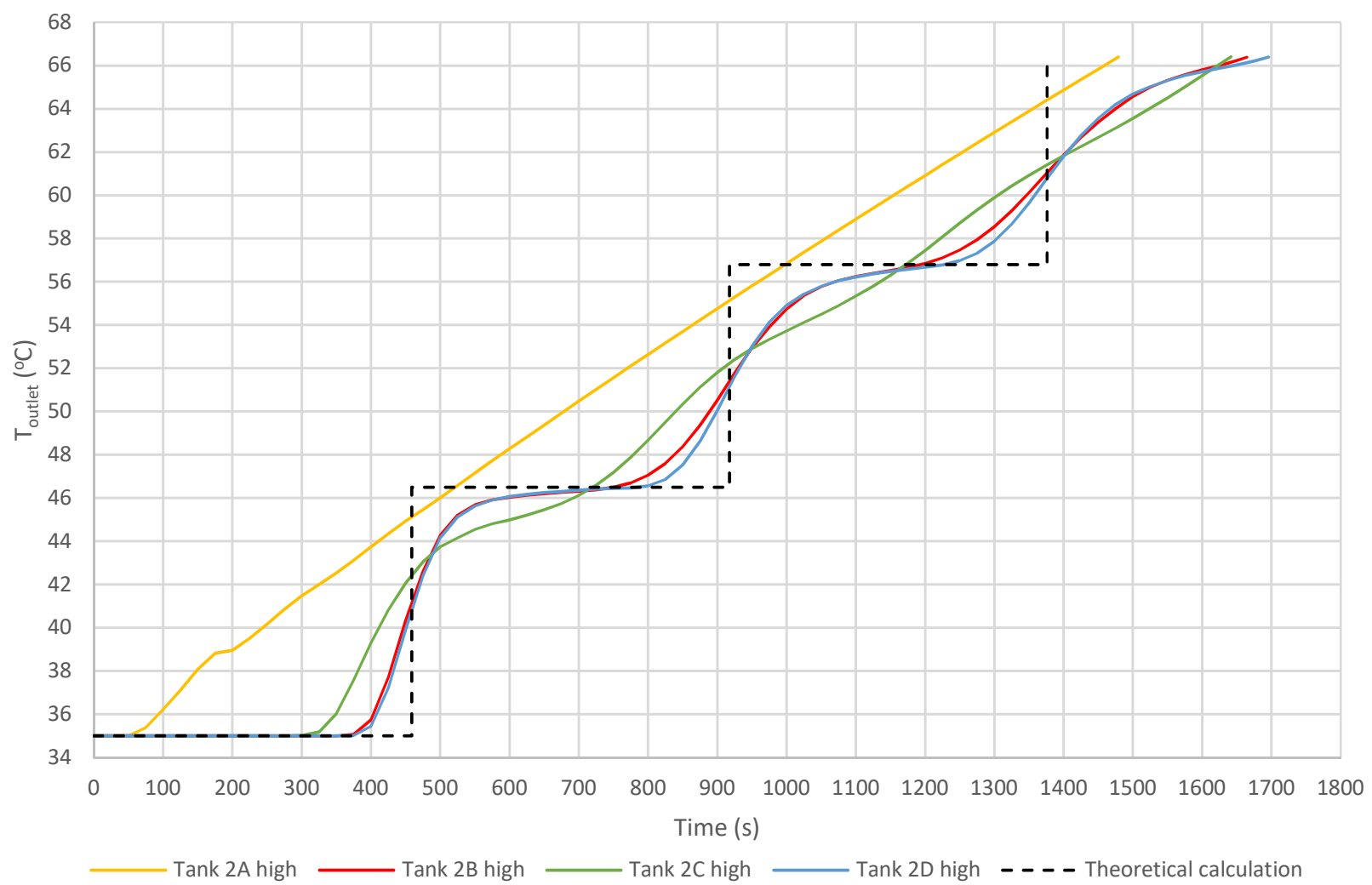

Figure 18: Average temperature at tank outlet during charge - high flow rate $(h / d=2)$ 


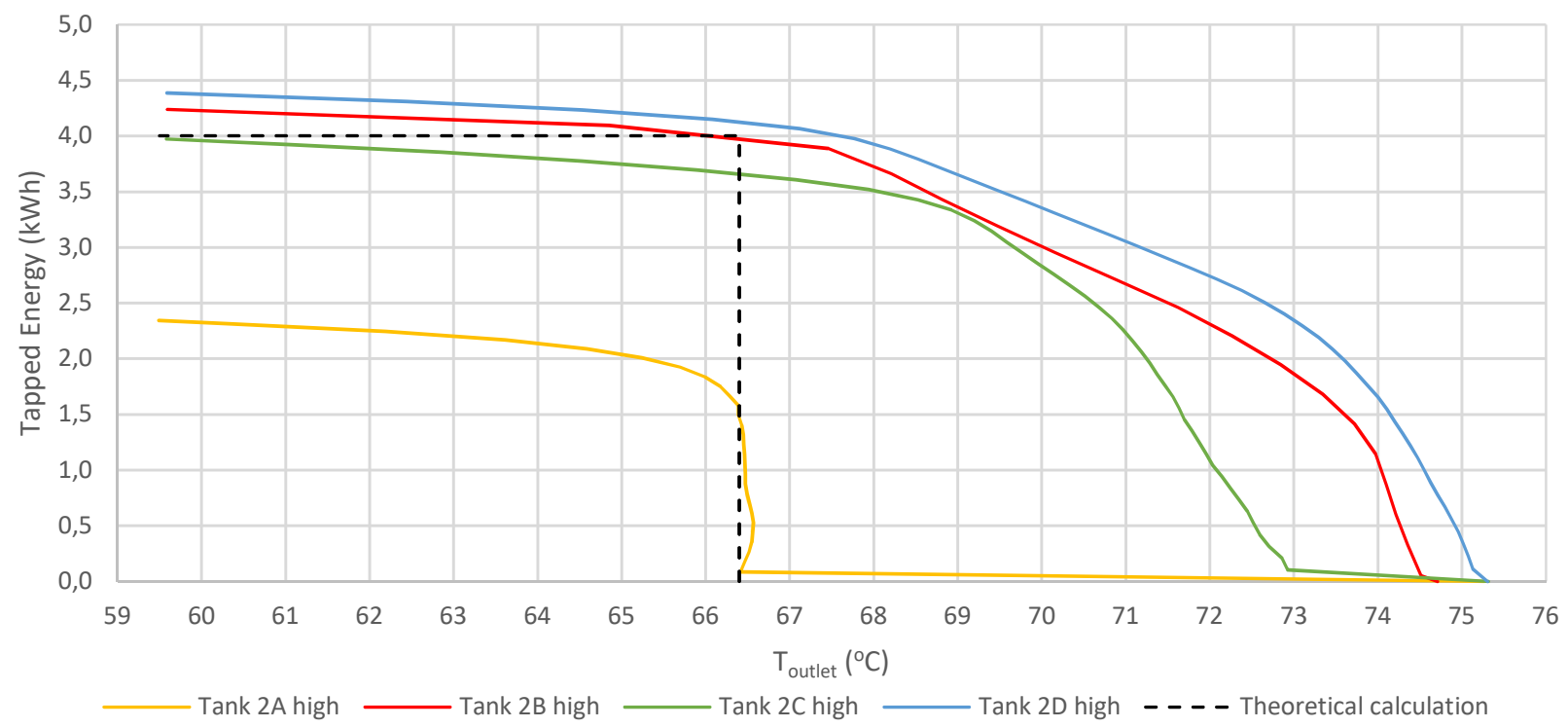

Figure 19: Tapped energy during discharge for a given outlet temperature - high flow rate $(h / d=2)$

Table 6: COP and residual energy calculation for $h / d=2$ tank for high and low flow rate

\begin{tabular}{cccc}
\hline Case & COP $_{\mathbf{1}}$ & COP $_{\mathbf{2}}$ & Residual Energy (kWh) \\
\hline Tank 2A high & 3.48 & 1.92 & 1.73 \\
Tank 2B high & 3.58 & 3.13 & 0.46 \\
Tank 2C high & 3.56 & 2.98 & 0.67 \\
Tank 2D high & 3.57 & 3.17 & 0.43 \\
Tank 2A low & 3.51 & 2.69 & 0.96 \\
Tank 2B low & 3.55 & 3.17 & 0.40 \\
Tank 2C low & 3.52 & 3.07 & 0.53 \\
Tank 2D low & 3.52 & 3.18 & 0.42 \\
\hline
\end{tabular}

\subsection{Tank $h / d=1$}

Figure 20 and Figure 21 present respectively the charge and discharge operations with high flow rate and $\mathrm{h} / \mathrm{d}$ ratio of 1 . It can be noticed that the lower the $\mathrm{h} / \mathrm{d}$ ratio gets, the larger the mixing in the tank and thus the thermal stratification in the tank becomes worse. 


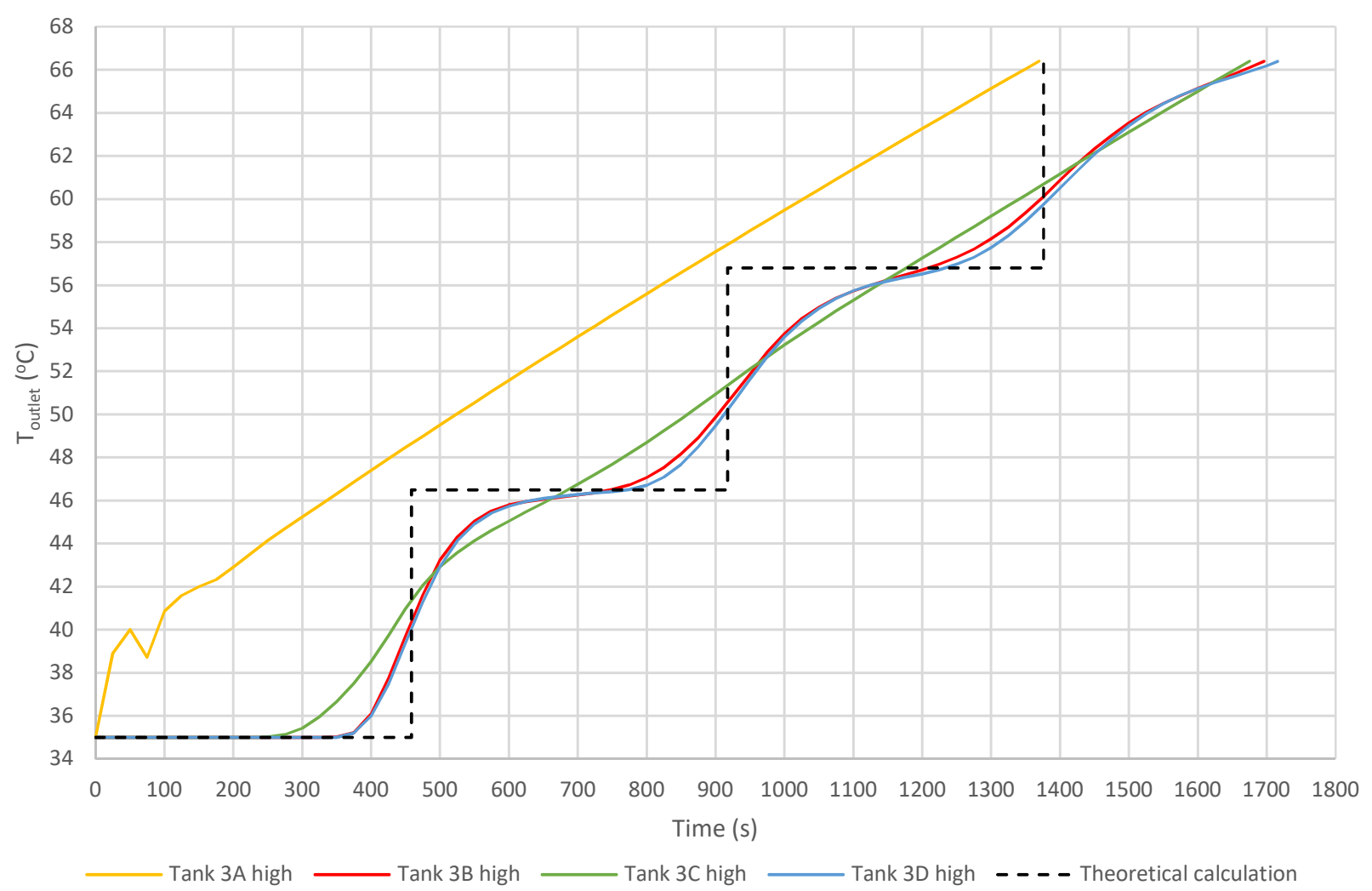

Figure 20: Average temperature at tank outlet during charge - high flow rate $(h / d=1)$

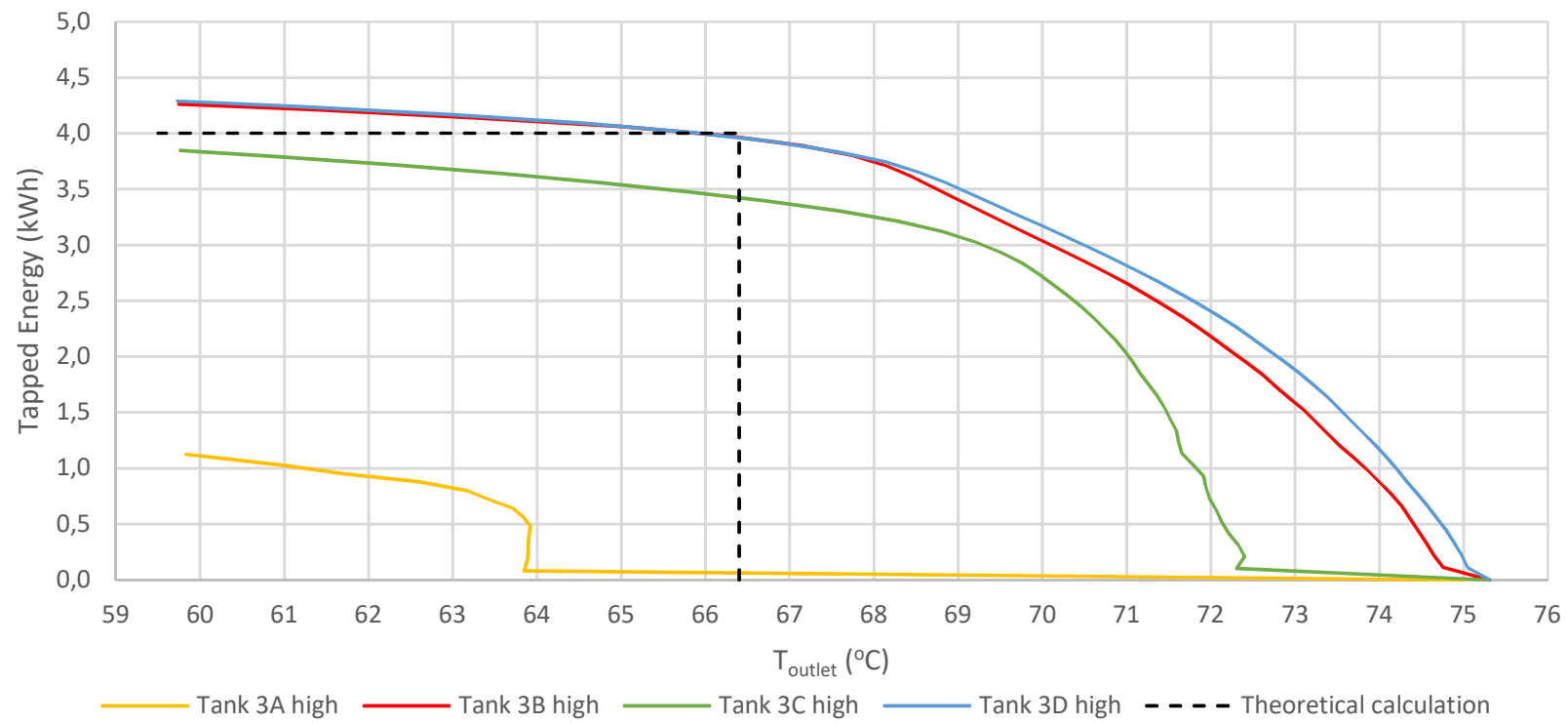

Figure 21: Tapped energy during discharge for a given outlet temperature - high flow rate $(h / d=1)$

Figure 21 shows that the tank without a diffuser (Tank 3A) had very small amount of energy tapped. An explanation is that due to the lower height of the tank $(0.52 \mathrm{~m})$, inlet water jet with high flow rate flows almost directly from the inlet to the outlet, forming a shortcut of flow in the tank and consequently resulting in an inefficient discharge with poor performance. 
The cases for tanks with $\mathrm{h} / \mathrm{d}=1$ had the lowest system COP and the highest residual energy among the ones investigated. This was expected due to the more intense mixing that occurs inside short tanks with large diameter. Not surprisingly, also in this case, the presence of a perforated plate diffuser (Tank 3D) or a long-single plate diffuser (Tank 3B), improved significantly the system COP and lowered the residual energy.

Table 7: COP and residual energy calculation for $h / d=1$ tank for high and low flow rate

\begin{tabular}{cccc}
\hline Case & COP $_{\mathbf{1}}$ & COP $_{\mathbf{2}}$ & Residual Energy (kWh) \\
\hline Tank 3A high & 3.38 & 0.98 & 3.35 \\
Tank 3B high & 3.51 & 3.04 & 0.55 \\
Tank 3C high & 3.46 & 2.82 & 0.84 \\
Tank 3D high & 3.48 & 3.09 & 0.52 \\
Tank 3A low & 3.39 & 2.22 & 1.46 \\
Tank 3B low & 3.47 & 3.07 & 0.56 \\
Tank 3C low & 3.44 & 2.95 & 0.68 \\
Tank 3D low & 3.46 & 3.13 & 0.48 \\
\hline
\end{tabular}

\subsection{No tank material}

An ideal case without any tank material was tested. The absence of material meant that the simulated case had no heat transfer between the water and tank wall and no possibility to store heat in the tank walls. As it can be seen in Figure 22 and Figure 23, the "No material-Tank 1D high" case, came very close to the "ideal case". The difference between the "ideal case" and the simulation occurs due to mixing inside the tank and thermal conduction downwards in the tank water.

In Table 8, the simulated case having the highest COP is presented, along with the same case without a tank material and the "ideal case". It can be observed that when there is no heat transfer between the water and tank wall, no vertical conduction and no mixing inside the tank (ideal case), the system COP after a charge-discharge cycle is 3.69. When the effect of mixing and vertical thermal conduction in the water are taken into account (No material-Tank 1D case), even if the case is optimized regarding mixing, the obtained COP is decreased by approximately $9 \%$. If heat transfer to the tank wall is also taken into account (Tank 1D high case), then the obtained COP is lowered by another $5 \%$ (so approximately $14 \%$ in total).

In addition, in Table 8, it can be seen that the "ideal case" is the only one that has a $\mathrm{COP}_{2}$ larger than $\mathrm{COP}_{1}$. The reason for this is that, it is the only case where the entire volume of the tank can be discharged since there is no mixing with the cold water and no heat transfer to the tank walls. This fact, combined also with the low electricity consumption (since it takes less time to charge the tank compared to the simulated cases) led to a higher $\mathrm{COP}_{2}$.

It can also be observed that the "ideal case" is able to discharge the whole volume of the tank leaving no residual energy due to the absence of mixing, while this is not the case for the other solutions. 


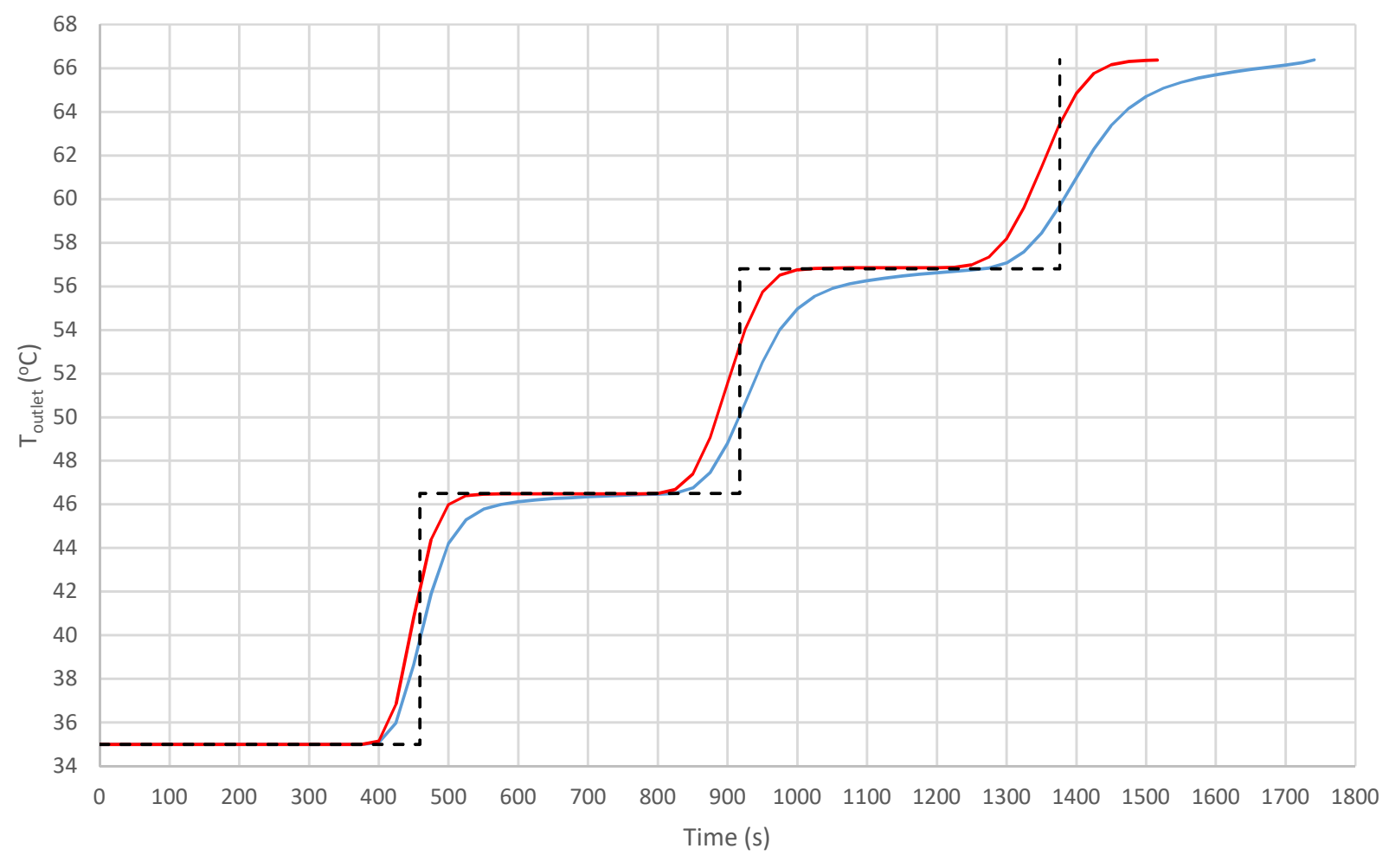

Tank 1D high _ No material - Tank 1D high _ _ _ - Theoretical calculation

Figure 22: Average temperature at tank outlet during charge for cases with and without tank material - high flow rate $(h / d=3.64)$

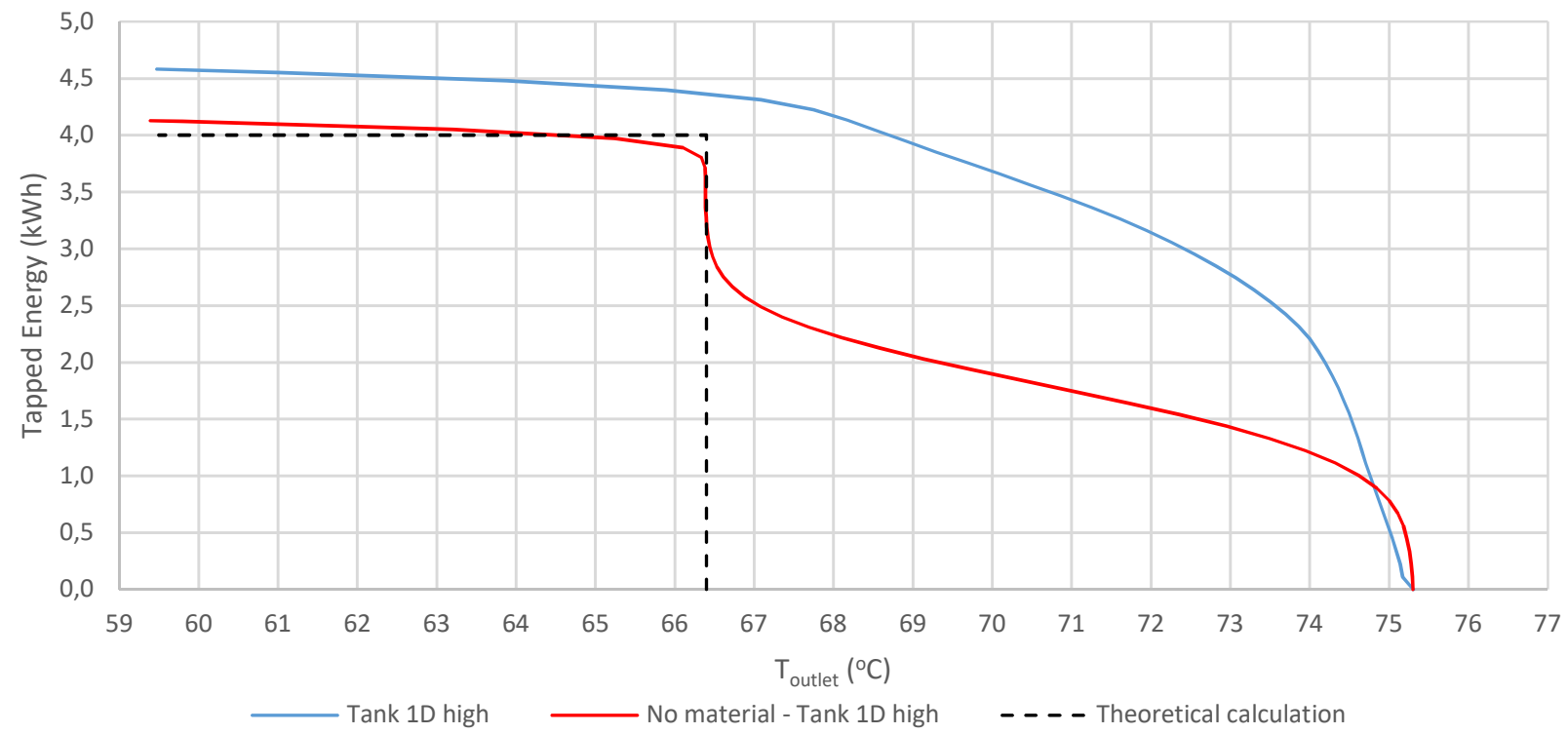

Figure 23: Tapped energy during discharge for a given outlet temperature for cases with and without tank material - high flow rate $(h / d=3.64)$ 
Table 8: COP and residual energy comparison between best performing cases

\begin{tabular}{cccc}
\hline Case & COP $_{\mathbf{1}}$ & COP $_{\mathbf{2}}$ & Residual Energy (kWh) \\
\hline Tank 1D high & 3.49 & 3.22 & 0.34 \\
No material - Tank 1D high & 3.54 & 3.38 & 0.2 \\
Ideal Case & 3.65 & 3.69 & 0 \\
\hline
\end{tabular}

\section{Conclusion}

A heating system consisting of a heat pump connected to a water tank was investigated by CFD simulations. A CFD model of the heat storage tank was developed and validated against measurements on a test tank. Two different system COPs were used to evaluate performance of the heating system: one based only on charge operation and the other on both charge and discharge operations. A parametric study was carried out using the validated CFD models to investigate the influence of tank designs and operation conditions on thermal stratification in the tank and on the COP of the heating system. Three different tank designs with tank height to diameter ratios in the range 1-3.64 and two flow rates were investigated. The results shows that the CFD model can predict accurately thermal stratification in the tank. It was found that there is a direct connection between the stratification in the tank and the COP of the heating system, as higher degree of thermal stratification lead to higher COP. For the ideal case where there is no mixing and no vertical thermal conduction in the tank and no heat loss from the tank, the system COP after a charge-discharge cycle is 3.69. When the effect of mixing is taken into account, the obtained COP of the system is decreased by approximately $9 \%$. If heat transfer to the tank wall and vertical thermal conduction are also taken into account, the obtained system COP is lowered by another $5 \%$. Moreover, the COP of a heating system with high flow rates can be significantly increased by a diffuser plate installed in the tank with a small distance to the inlet/outlet. The best performing system studied was the system based on an insulated tall and slim tank with a high h/d ratio of 3.64 and a perforated plate diffuser. The performance of the suggested system was not affected by the tested variations in flow rate. It should be noted that the finding of the paper is valid for tanks with flat ends (with shapes similarly to the ones presented in the paper) and the optimal design of diffuser might be different for tanks with round ends.

\section{Acknowledgements}

The project participants in the "Highly Efficient and Simplified Thermodynamic Cycle with Isolated Heating and Cooling - Cost Optimized (ISECOP)" are: Danish Technological Institute, Technical University of Denmark, Vengcon, Alfa Laval, METRO THERM, Svedan Industri Køleanlæg, CHR Møller, Egå Smede- og Maskinværksted and ARLA FOODS (Madsen, 2017). This research was carried out in the ISECOP-EUDP project supported by the Danish Energy Agency. 


\section{References}

Abdelhak, O., Mhiri, H., Bournot, P., 2015. CFD analysis of thermal stratification in domestic hot water storage tank during dynamic mode. Build. Simul. 8, 421-429. https://doi.org/10.1007/s12273-015-0216-9

Alizadeh, S., 1999. An experimental and numerical study of thermal stratification in a horizontal cylindrical solar storage tank. Sol. Energy 66, 409-421. https://doi.org/10.1016/S0038-092X(99)00036-5

Altuntop, N., Arslan, M., Ozceyhan, V., Kanoglu, M., 2005. Effect of obstacles on thermal stratification in hot water storage tanks. Appl. Therm. Eng. 25, 2285-2298. https://doi.org/10.1016/j.applthermaleng.2004.12.013

Andersen, E., Furbo, S., Hampel, M., Heidemann, W., Müller-Steinhagen, H., 2008. Investigations on stratification devices for hot water heat stores. Int. J. Energy Res. 32, 255-263. https://doi.org/10.1002/er.1345

Arslan, M., Altuntop, N., Ozceyhan, V., Kanoglu, M., 2006. Optimum Dimensions of an Obstacle Placed in a Hot Water Tank for Thermal Stratification. Energy Explor. Exploit. 23, 357-373. https://doi.org/10.1260/014459805775992708

Arteconi, A., Hewitt, N.J., Polonara, F., 2013. Domestic demand-side management (DSM): Role of heat pumps and thermal energy storage (TES) systems. Appl. Therm. Eng. 51, 155-165. https://doi.org/10.1016/j.applthermaleng.2012.09.023

Bouhal, T., Fertahi, S., Agrouaz, Y., El Rhafiki, T., Kousksou, T., Jamil, A., 2017. Numerical modeling and optimization of thermal stratification in solar hot water storage tanks for domestic applications: CFD study. Sol. Energy 157, 441-455. https://doi.org/10.1016/j.solener.2017.08.061

Carola, B., Thorsten, U., Stefan, G., Bernd, P., Rolf, L., 2012. Hot water storages: Influence of geometry and operation parameters on thermal stratification. Euroheat and Power 9, 30-36.

Castell, A., Medrano, M., Solé, C., Cabeza, L.F., 2010. Dimensionless numbers used to characterize stratification in water tanks for discharging at low flow rates. Renew. Energy 35, 2192-2199. https://doi.org/10.1016/j.renene.2010.03.020

Cebeci, T., Shao, J.P., Kafyeke, F., Laurendeau, E., 2005. Computational Fluid Dynamics for Engineers: From Panel to NavierStokes Methods with Computer Programs, 1st ed. Springer-Verlag Berlin Heidelberg. https://doi.org/10.1007/3-54027717-X

Chua, K.J., Chou, S.K., Yang, W.M., 2010. Advances in heat pump systems: A review. Appl. Energy 87, 3611-3624. https://doi.org/10.1016/j.apenergy.2010.06.014

Cristofari, C., Notton, G., Poggi, P., Louche, A., 2003. Influence of the flow rate and the tank stratification degree on the performances of a solar flat-plate collector. Int. J. Therm. Sci. 42, 455-469. https://doi.org/10.1016/S12900729(02)00046-7

D'Ettorre, F., Conti, P., Schito, E., Testi, D., 2019. Model predictive control of a hybrid heat pump system and impact of the prediction horizon on cost-saving potential and optimal storage capacity. Appl. Therm. Eng. 148, 524-535. https://doi.org/10.1016/j.applthermaleng.2018.11.063

Dragsted, J., Furbo, S., Dannemand, M., Bava, F., 2017. Thermal stratification built up in hot water tank with different inlet stratifiers. Sol. Energy 147, 414-425. https://doi.org/10.1016/j.solener.2017.03.008

Erdemir, D., Altuntop, N., 2016. Improved thermal stratification with obstacles placed inside the vertical mantled hot water tanks. Appl. Therm. Eng. 100, 20-29. https://doi.org/10.1016/j.applthermaleng.2016.01.069

Fan, J., Furbo, S., 2012a. Buoyancy driven flow in a hot water tank due to standby heat loss. Sol. Energy 86, 3438-3449. https://doi.org/10.1016/j.solener.2012.07.024

Fan, J., Furbo, S., 2012b. Thermal stratification in a hot water tank established by heat loss from the tank. Sol. Energy 86, 34603469. https://doi.org/10.1016/j.solener.2012.07.026

Fernandez-Seara, J., Uhia, F.J., Sieres, J., 2007. Experimental analysis of a domestic electric hot water storage tank . Part II : dynamic mode of operation. Appl. Therm. Eng. 27, 137-144. https://doi.org/10.1016/j.applthermaleng.2006.05.004

Furbo, S., Vejen, N.K., Shah, L.J., 2005. Thermal Performance of a Large Low Flow Solar Heating System With a Highly Thermally Stratified Tank. J. Sol. Energy Eng. 127, 15. https://doi.org/10.1115/1.1767190

García-Marí, E., Gasque, M., Gutiérrez-Colomer, R.P., Ibáñez, F., González-Altozano, P., 2013. A new inlet device that enhances 
thermal stratification during charging in a hot water storage tank. Appl. Therm. Eng. 61, 663-669. https://doi.org/10.1016/j.applthermaleng.2013.08.023

Gasque, M., González-Altozano, P., Maurer, D., Moncho-Esteve, I.J., Gutiérrez-Colomer, R.P., Palau-Salvador, G., Garciá-Marí, E., 2015. Study of the influence of inner lining material on thermal stratification in a hot water storage tank. Appl. Therm. Eng. 75, 344-356. https://doi.org/10.1016/j.applthermaleng.2014.10.040

GEA-Group, 2019. GEA Vap 11 - Stationary Applications [WWW Document]. URL https://vap.gea.com/stationaryapplication/Pages/Index.aspx (accessed 2.1.19).

Gómez, M.A., Collazo, J., Porteiro, J., Míguez, J.L., 2018. Numerical study of an external device for the improvement of the thermal stratification in hot water storage tanks. Appl. Therm. Eng. 144, 996-1009. https://doi.org/10.1016/j.applthermaleng.2018.09.023

Hollands, K.G.T., Lightstone, M.F., 1989. A review of low-flow, stratified-tank solar water heating systems. Sol. Energy 43, 97105. https://doi.org/10.1016/0038-092X(89)90151-5

Hu, B., Li, Y., Cao, F., Xing, Z., 2015. Extremum seeking control of COP optimization for air-source transcritical CO2 heat pump water heater system. Appl. Energy 147, 361-372. https://doi.org/10.1016/j.apenergy.2015.03.010

IPU, 2019. CoolPack [WWW Document]. URL https://www.ipu.dk/products/coolpack/ (accessed 2.1.19).

Jordan, U., Furbo, S., 2005. Thermal stratification in small solar domestic storage tanks caused by draw-offs. Sol. Energy 78, 291-300. https://doi.org/10.1016/j.solener.2004.09.011

Knudsen, S., Furbo, S., 2004. Thermal stratification in vertical mantle heat-exchangers with application to solar domestic hotwater systems. Appl. Energy 78, 257-272. https://doi.org/10.1016/j.apenergy.2003.09.002

Kozłowska, K., Jadwiszczak, P., 2018. The impact of inflow velocity on thermal stratification in a water storage tank. E3S Web Conf. 44, 00079. https://doi.org/10.1051/e3sconf/20184400079

Li, S., Zhang, Y., Li, Y., Zhang, X., 2014. Experimental study of inlet structure on the discharging performance of a solar water storage tank. Energy Build. 70, 490-496. https://doi.org/10.1016/j.enbuild.2013.11.086

Li, W., Hrnjak, P., 2018. Experimentally validated model of heat pump water heater with a water tank in heating-up transients. Int. J. Refrig. 88, 420-431. https://doi.org/10.1016/j.ijrefrig.2018.01.020

Lohse, R., Urbaneck, T., Bramer, C., Platzer, B., 2012. Effects during loading of hot water storages with a high aspect ratio. EuroHeat \& Power 9, 42-47.

Madsen, C., 2017. Highly Efficient and Simplified Thermodynamic Cycle with Isolated Heating and Cooling - Cost Optimized (ISECOP) [WWW Document]. energiforskniong.dk. Offentligt støttede danske energiprojekter. URL https://energiforskning.dk/node/9012 (accessed 3.19.19).

Meyer, J.P., Raubenheimer, P.J.A., Krüger, E., 2000. The influence of return loop flow rate on stratification in a vertical hot water storage tank connected to a heat pump water heater. Heat Transf. Eng. 21, 67-73. https://doi.org/10.1080/014576300271040

Minetto, S., 2011. Theoretical and experimental analysis of a CO2 heat pump for domestic hot water. Int. J. Refrig. 34, 742-751. https://doi.org/10.1016/j.ijrefrig.2010.12.018

Moncho-Esteve, I.J., Gasque, M., González-Altozano, P., Palau-Salvador, G., 2017. Simple inlet devices and their influence on thermal stratification in a hot water storage tank. Energy Build. 150, 625-638. https://doi.org/10.1016/j.enbuild.2017.06.012

Nizami, D.J., Lightstone, M.F., Harrison, S.J., Cruickshank, C.A., 2013. Negative buoyant plume model for solar domestic hot water tank systems incorporating a vertical inlet. Sol. Energy 87, 53-63. https://doi.org/10.1016/j.solener.2012.10.001

Olsen, L., Gaunaa, V., Madsen, C., Olesen, M.F., 2015. High efficient heat pump system using storage tanks to increase COP by means of the ISEC concept -Part 1: Model validation, in: Proceedings of the 24th ICR International Congress of Refrigeration. Yokohama, Japan. https://doi.org/10.1074/jbc.M110.154963

Olsen, L., Madsen, C., Olesen, M.F., Rothuizen, E., Elmegaard, B., Markussen, W.B., 2016. Highly Efficient Thermodynamic Cycle with Isolated System Energy Charging (ISEC) - Final report. Danish Technological Institute and Technical University of 
Denmark.

Rothuizen, E., Madsen, C., Elmegaard, B., Olesen, M., Markussen, W.B., 2014. High Efficient Ammonia Heat Pump Sustem for Industrial Process Water Using the ISEC Concept - Part I. 11th IIR Gustav Lorenzen Conf. Nat. Refrig. https://doi.org/10.1016/j.jengtecman.2011.09.011

Savicki, D.L., Vielmo, H.A., Krenzinger, A., 2011. Three-dimensional analysis and investigation of the thermal and hydrodynamic behaviors of cylindrical storage tanks. Renew. Energy 36, 1364-1373. https://doi.org/10.1016/j.renene.2010.10.011

Shah, L.J., Furbo, S., 2003. Entrance effects in solar storage tanks. Sol. Energy 75, 337-348. https://doi.org/10.1016/j.solener.2003.04.002

Shin, M., Lee, Y., Yoon, H., 2004. Numerical and experimental study on the design of a stratified thermal storage system. Appl. Therm. Eng. 24, 17-27. https://doi.org/10.1016/S1359-4311(03)00242-4

Wang, K., Cao, F., Wang, S., Xing, Z., 2010. Investigation of the performance of a high-temperature heat pump using parallel cycles with serial heating on the water side. Int. J. Refrig. 33, 1142-1151. https://doi.org/10.1016/j.ijrefrig.2010.04.016

Wang, S., Tuo, H., Cao, F., Xing, Z., 2013. Experimental investigation on air-source transcritical CO2 heat pump water heater system at a fixed water inlet temperature. Int. J. Refrig. 36, 701-716. https://doi.org/10.1016/j.jjrefrig.2012.10.011

Wang, Z., Zhang, H., Dou, B., Huang, H., Wu, W., Wang, Z., 2017. Experimental and numerical research of thermal stratification with a novel inlet in a dynamic hot water storage tank. Renew. Energy 111, 353-371. https://doi.org/10.1016/j.renene.2017.04.007

Yaïci, W., Ghorab, M., Entchev, E., Hayden, S., 2013. Three-dimensional unsteady CFD simulations of a thermal storage tank performance for optimum design. Appl. Therm. Eng. 60, 152-163. https://doi.org/10.1016/j.applthermaleng.2013.07.001

Zachár, A., Farkas, I., Szlivka, F., 2003. Numerical analyses of the impact of plates for thermal stratification inside a storage tank with upper and lower inlet flows. Sol. Energy 74, 287-302. https://doi.org/10.1016/S0038-092X(03)00188-9

Zhu, N., Hu, P., Xu, L., Jiang, Z., Lei, F., 2014. Recent research and applications of ground source heat pump integrated with thermal energy storage systems: A review. Appl. Therm. Eng. 71, 142-151. https://doi.org/10.1016/j.applthermaleng.2014.06.040 